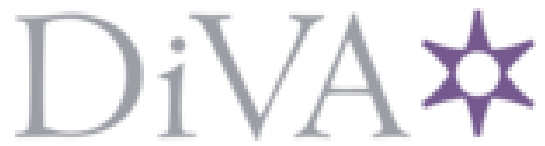

http://www.diva-portal.org

\title{
Postprint
}

This is the accepted version of a paper published in . This paper has been peer-reviewed but does not include the final publisher proof-corrections or journal pagination.

Citation for the original published paper (version of record):

Ashour, R., Samouhos, M., Polido Legaria, E., Svärd, M., Högblom, J. et al. (2018)

DTPA-Functionalized Silica Nano- and Microparticles for Adsorption and

Chromatographic Separation of Rare Earth Elements

ACS Sustainable Chemistry \& Engineering, 6(5): 6889-6900

https://doi.org/10.1021/acssuschemeng.8boo725

Access to the published version may require subscription.

N.B. When citing this work, cite the original published paper.

Permanent link to this version:

http://urn.kb.se/resolve?urn=urn:nbn:se:kth:diva-226580 


\section{DTPA-functionalized silica nano- and microparticles for adsorption and chromatographic separation of rare earth elements}

Radwa M. Ashour, ${ }^{\dagger \dagger}$ Michail Samouhos, ${ }^{\S}$ Elizabeth Polido Legaria, ${ }^{\S}$ Michael Svärd, ${ }^{\dagger}$ Joakim Högblom, ${ }^{\|}$Kerstin Forsberg, ${ }^{\dagger}$ Magnus Palmlöf," Vadim G. Kessler, ${ }^{\S}$ Gulaim A. Seisenbaeva ${ }^{\S}$ and Åke C. Rasmuson*广

${ }^{\dagger}$ Department of Chemical Engineering, KTH Royal Institute of Technology, Teknikringen 42, SE-100 44 Stockholm, Sweden

Nuclear Materials Authority, P.O. Box 530, El Maadi, Cairo, Egypt

$\S$ Department of Molecular Sciences, Biocenter, Swedish University of Agricultural Sciences, Box 7015, SE-75007 Uppsala, Sweden

"AkzoNobel, Pulp and Performance Chemicals AB, Färjevägen 1, SE-445 80 Bohus, Sweden *Corresponding author. Email: $\underline{\text { akera } @ \text {,kth.se }}$

\section{Open access version declaration}

This is the accepted version of the article: ACS Sustainable Chem. Eng. 2018, 6(5), 6889-6900 DOI: $10.1021 /$ acssuschemeng.8b00725

Link to publication: https://pubs.acs.org/doi/abs/10.1021/acssuschemeng.8b00725 


\section{DTPA-functionalized silica nano- and microparticles}

\section{for adsorption and chromatographic separation of}

\section{rare earth elements}

Radwa M. Ashour, ${ }^{\dagger, \ddagger}$ Michail Samouhos,${ }^{\S}$ Elizabeth Polido Legaria, ${ }^{\S}$ Michael Svärd, ${ }^{\dagger}$ Joakim Högblom, ${ }^{\Downarrow}$ Kerstin Forsberg, ${ }^{\dagger}$ Magnus Palmlöf, ${ }^{\Downarrow}$ Vadim G. Kessler, ${ }^{\S}$ Gulaim A. Seisenbaeva ${ }^{\S}$ and Åke C. Rasmuson*†

${ }^{\dagger}$ Department of Chemical Engineering, KTH Royal Institute of Technology, Teknikringen 42, SE-100 44 Stockholm, Sweden

$\$$ Nuclear Materials Authority, P.O. Box 530, El Maadi, Cairo, Egypt

$\S$ Department of Molecular Sciences, Biocenter, Swedish University of Agricultural Sciences, Box 7015, SE-75007 Uppsala, Sweden

"AkzoNobel, Pulp and Performance Chemicals AB, Färjevägen 1, SE-445 80 Bohus, Sweden

*Corresponding author. Email: akera@,kth.se

KEYWORDS Rare earth elements, Chelation ion chromatography, Separation, Diethylenetriaminepentaacetic acid, Hybrid nanoadsorbent. 


\begin{abstract}
Silica nanoparticles and porous microparticles have been successfully functionalized with a monolayer of DTPA-derived ligands. The ligand grafting is chemically robust and does not appreciably influence the morphology or the structure of the material. The produced particles exhibit quick kinetics and high capacity for REE adsorption. The feasibility of using the DTPAfunctionalized microparticles for chromatographic separation of rare earth elements has been investigated for different sample concentrations, elution modes, eluent concentrations, eluent flow rates and column temperatures. Good separation of the $\mathrm{La}(\mathrm{III}), \mathrm{Ce}(\mathrm{III}), \mathrm{Pr}(\mathrm{III}), \mathrm{Nd}(\mathrm{III})$ and Dy(III) ions was achieved using $\mathrm{HNO}_{3}$ as eluent using a linear concentration gradient from $0 \mathrm{M}$ to $0.15 \mathrm{M}$ over $55 \mathrm{~min}$. The long-term performance of the functionalized column has been verified, with very little deterioration recorded over more than 50 experiments. The results of this study demonstrate the potential for using DTPA-functionalized silica particles in a chromatographic process for separating these valuable elements from waste sources, as an environmentally preferable alternative to standard solvent-intensive processes.
\end{abstract}




\section{INTRODUCTION}

Rare earth elements (REEs) comprise the lanthanide series together with scandium (Sc) and yttrium (Y) (because Sc and Y have similar physico-chemical properties to the lanthanides and often occur along with them in natural minerals). ${ }^{1-2}$ During the last few decades, REEs have gained considerable attention due to their unique properties and their use in a huge range of industrial applications such as petroleum refining catalysts, fluorescent glass, permanent magnets and rechargeable batteries for electric vehicles. ${ }^{3-8}$ Industrial demand for REEs has increased and is expected to multiply during the next decade, and prices usually depend strongly on the level of purity. The separation of REEs can be difficult due to similarities in physical and chemical properties. Efforts have been made to develop technologies for efficiently extracting these valuable metal ions from various waste sources, including ores, wastewater and recycling from in particular fluorescent lamp waste..$^{9-11}$ Many strategies have been employed for pre-concentrating, separation and recovery of REEs, including precipitation, ${ }^{12}$ electrochemical extraction, ${ }^{13}$ ion-exchange ${ }^{14}$ and ionic liquid extraction. ${ }^{15}$ However, in general these methods require large quantities of harmful or expensive reagents such as strong acids and extractant compounds. The most common technique used in industrial scale today is solvent extraction. ${ }^{5,16-18}$ Large scale solvent extraction involves large quantities of organic solvents, leading to high material costs as well as risks of water contamination by toxic chemicals. ${ }^{19}$ Separations based on adsorption or ion chromatography (IC) are attractive, greener alternatives that are applied for sample analysis and purification in different areas. ${ }^{20-23}$ High-performance chelation ion chromatography (HPCIC) is a promising technique previously shown to be applicable to individual separation of REEs. ${ }^{24-26} \mathrm{HPCIC}$ is a mode of ion chromatography based on the formation and dissociation of complexes formed on the surface of a ligand-functionalized stationary phase. ${ }^{27-29}$ The main advantage of HPCIC is the possibility to use 
common, recoverable mineral acids as eluent like in ion-exchange chromatography, while the stationary phase has complex forming properties like in ion-pairing chromatography. Consequently, it constitutes a promising green technique for separation and recovery of metals when a high purity is desirable. Recently, analytical HPCIC separation of REEs using silica or polymer-based sorbents with various chelating reagents and mineral acids such as $\mathrm{HCl}$ or $\mathrm{HNO}_{3}$ as eluent has been investigated. ${ }^{26}$ Amino-polycarboxylic acid reagents are common types of chelating agents shown to possess superior efficiency for REE separation. The structures of functional carboxylic ligands, often referred to as complexonate ligands, contain carboxylic groups within the molecule in proximity to other binding functionalities, which can provide alternative and possibly more specific selectivity, such as in iminodiacetic acid (IDA), ${ }^{30-32}$ ethylenediaminetetraacetic acid $\left(\right.$ EDTA), ${ }^{33}$ nitrilotriacetic acid (NTA), ${ }^{34}$ propylenediaminetetraacetic acid (PDTA) $)^{35}$ and hydroxyisobutyric acid (HIBA). ${ }^{36-37}$ Chromatographic techniques including extraction and chelation ion chromatography have recently been proposed and evaluated for the separation and determination of REEs. ${ }^{38-40}$ Max-Hansen et al. ${ }^{38}$ investigated preparative separation of lanthanides using a di-(2-ethylhexyl)-phosphoric acid (HDEHP) impregnated $\mathrm{Kromasil}^{\circledR}-\mathrm{C} 18$ column, with up to $7 \mathrm{M}$ of $\mathrm{HNO}_{3}$ as eluent in a gradient elution process. Ramzan et al. ${ }^{39}$ studied analytical scale separation of REEs using C18-silica columns impregnated with different extractants, including HDEHP, 2-ethylhexyl, 2ethylhexylphosphonic acid (H[(EH)EHP]) and di-(2,4,4-trimethylpentyl)-phosphinic acid ( $\mathrm{H}[\mathrm{TMPeP}])$, and using up to $2 \mathrm{M}$ of $\mathrm{HNO}_{3}$ as eluent. Major disadvantage of impregnation lies in relatively easy leaching of the ligand from the matrix. An important improvement has been achieved by using polymeric functional ligands for impregnation. ${ }^{41-43}$ However, even in this case "bleeding" of the organic ligand remained an issue. ${ }^{44}$ 
Principal advantage in this respect is offered by the covalent grafting of ligand, eliminating the loss of the organic function. Thus Nesterenko et al. ${ }^{30}$ achieved isocratic HPCIC separation of 14 lanthanides and yttrium using a column packed with IDA functionalized silica particles, and up to $0.7 \mathrm{M} \mathrm{KNO}_{3}$ as eluent. Aside from chromatography, other new approaches based on the use of functional solid adsorbents have been developed for REE separation. The early work on surface functionalized resin-like organosilicas has been summarized by Voronkov et al ${ }^{45}$ The focus was initially on ion-exchange functions such as sulfonate, but has later shifted towards more REEselective phosphonate ligands. ${ }^{46-47}$ In the search for approaches for facilitated separation of adsorbents and their further regeneration, the use of magnetic particles coated by protective dense silica layers has been developed. The particles thus produced are infinitely stable in highly acidic media, permitting their multiple use. ${ }^{48}$ Pursuing the aim of increased selectivity has led to nanoparticles functionalized with chelating amino carboxylate ligands. ${ }^{49}$ Adsorbents bearing complexonate ligands such as polydopamine (PDA), ${ }^{50}$ IDA,,${ }^{51}$ L-cysteine, ${ }^{52}$ EDTA ${ }^{53}$ and ophosphorylethanolamine ${ }^{54}$ have revealed high capacity and appreciable selectivity towards preferred retention of smaller (heavier) REE ions as well as actinides. ${ }^{55} \mathrm{X}$-ray single crystal structure determination of REE complexes with selected ligands has provided molecular insight into potential reasons of selectivity for produced adsorbents. ${ }^{51}$ It has been proposed that by increasing the number of carboxylate groups of a ligand it would be possible to improve the capacity without compromising the selectivity.

The present work is focused on evaluating the industrial application of a facile, environmentally friendly and efficient method for separation and recovery of REEs from dilute aqueous solutions. On one hand, our aim has been to evaluate a new ligand, to the best of our knowledge never before applied to either adsorbent materials or for chromatographic applications - 
diethylenetriaminepentaacetic acid (DTPA). DTPA is an octadentate aminopolycarboxylate chelating agent, with important practical applications especially for trivalent actinide-lanthanide separations (Fig. 1) ${ }^{56-59}$. Based on a comparison of the adsorption properties of chemically related ligands TTHA and EDTA, DTPA is expected to give high selectivity and good uptake especially for medium REE. ${ }^{60}$ On the other hand, we have sought a direct comparison between commercially up-scalable materials - the aggregated dense particles of silica available from Sigma-Aldrich and mesoporous silica Kromasil ${ }^{\circledR}$ microparticles produced by AkzoNobel AB, as starting materials for preparation of nanoadsorbents for REE separation. HPCIC separation experiments were carried out for $\mathrm{La}(\mathrm{III}), \mathrm{Ce}(\mathrm{III}), \operatorname{Pr}(\mathrm{III}), \mathrm{Nd}(\mathrm{III}), \mathrm{Dy}(\mathrm{III})$ and $\mathrm{Y}(\mathrm{III})$ ions from aqueous solution using a column packed with functionalized Kromasil ${ }^{\circledR}$ and with $\mathrm{HNO}_{3}$ solution as eluent. The choice of model elements is based on their relative abundance in apatite ore, ${ }^{12}$ which is a targeted raw material for a potential process for recovery and separation of rare earth elements. The influence of temperature, eluent concentration, eluent flow rate and total sample load on the separation has been investigated, and the long-term stability of the column evaluated.

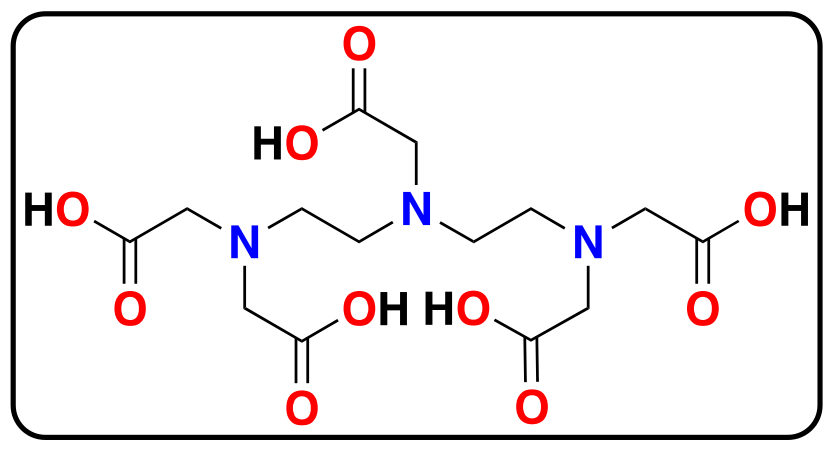

Figure 1. Chemical structure of the ligand DTPA. 


\section{EXPERIMENTAL}

\section{Chemicals and agents}

All chemicals used in the experiments were purchased as analytical grade reagents and used as received without further purification. All solutions were prepared in deionized water obtained from a Millipore Direct-Q3 water purification system (France). Diethylenetriaminepentaacetic acid dianhydride (DTPA, CAS 23911-26-4, 99\%), aminopropyl triethoxysilane (APTES, CAS 13822-56-5, 97\%) and silica nanoparticles (specific surface area: $175-225 \mathrm{~m}^{2} \mathrm{~g}^{-1}$, average diameter about $20 \mathrm{~nm}$ ) were purchased from Sigma Aldrich. Mesoporous Kromasil ${ }^{\circledR}$ particles (average size $10 \mu \mathrm{m}$, average pore size $100 \AA$ A , APTES-functionalized) were donated by AkzoNobel AB, Sweden. HPLC grade propanol and methanol were purchased from Sigma Aldrich. Single-elements standard solutions of $\mathrm{La}(\mathrm{III}), \mathrm{Ce}(\mathrm{III}), \mathrm{Pr}(\mathrm{III}), \mathrm{Nd}(\mathrm{III}), \mathrm{Dy}(\mathrm{III})$ and $\mathrm{Y}(\mathrm{III})$ ions in $2 \% \mathrm{HNO}_{3}$ were purchased from Inorganic Ventures (USA). A stock solution of $\mathrm{La}(\mathrm{III}), \mathrm{Ce}(\mathrm{III}), \mathrm{Pr}(\mathrm{III})$, $\mathrm{Nd}(\mathrm{III}), \mathrm{Dy}(\mathrm{III})$ and $\mathrm{Y}(\mathrm{III})$ was prepared at a concentration of $1000 \mathrm{mg} \mathrm{L}^{-1}$ (total REE concentration) by dilution with deionized water. The eluent $\left(0.3 \mathrm{M} \mathrm{HNO}_{3}\right)$ was prepared by transferring the appropriate volume of $69 \% \mathrm{HNO}_{3}$ to a $500 \mathrm{~mL}$ volumetric flask and diluting with deionized water. The post-column reagent (PCR) solution consisting of 0.15 $\mathrm{mM}$ Arsenazo III and $0.01 \mathrm{M}$ urea in $0.1 \mathrm{M}$ acetic acid was prepared by dissolution and dilution by deionized water. Arsenazo III and urea were supplied by Sigma Aldrich and acetic acid (96\%) from Merck. The eluent and PCR solutions were filtered through Munktell grade 5 filter paper before use. 


\section{Synthesis of model DTPA@ $@ \mathrm{SiO}_{2}$ particles}

Commercial $\mathrm{SiO}_{2}$ nanopowder $(5 \mathrm{~g})$ and a corresponding amount of APTES (using a $2 \mathrm{x}$ stoichiometrically required amount for the creation of a monolayer) was dissolved in $200 \mathrm{~mL}$ of ethanol and $62.5 \mathrm{~cm}^{3}$ of $1 \% \mathrm{NH}_{4} \mathrm{~F}$ solution in water. The suspension was stirred for $6 \mathrm{~h}$ at room temperature and then dried at room temperature under vacuum, while the amount of attached APTES was calculated using thermogravimetry. Subsequently, $4 \mathrm{~g}$ of $\mathrm{SiO}_{2}$-APTES and DTPA anhydride in the ratio 2:1 (w/w) to the attached APTES were dissolved in toluene $(400 \mathrm{~mL})$ and kept at $80^{\circ} \mathrm{C}$ with continuous stirring for $6 \mathrm{~h}$. The suspension was dried at room temperature under vacuum. The above procedure was repeated until the production of a total quantity of $25 \mathrm{~g}$ of $\mathrm{SiO}_{2}-$ DTPA hybrid particles had been achieved. The grafting method is described in detail in a previous publication. ${ }^{60}$

Adsorption and desorption of rare earth element ions (La(III), Nd(III) and Dy(III)) on DTPA@SiO 2 particles

Three $0.01 \mathrm{M}$ stock solutions of REE($\left(\mathrm{NO}_{3}\right)_{3}$ (light REEs La(III), Nd(III) and heavy REE Dy(III)) were prepared and mixed at molar ratio $1: 1: 1$, while subsequently $7.88 \mathrm{~mL}$ of the $\mathrm{La}(\mathrm{III})-\mathrm{Nd}(\mathrm{III})$ - Dy(III) salt solution was mixed with $2 \mathrm{~mL}$ of $1 \mathrm{M} \mathrm{NaNO}_{3}$ and diluted to $20 \mathrm{~mL}$ to achieve constant ionic strength. For each adsorption test $250 \mathrm{mg}$ of APTES-DTPA grafted nanosilica was added to the solution. The molar ratio between $\mathrm{RE}^{3+}$ ions and DTPA was 2:1. The mixture was shaken for various lengths of time in an orbital shaker at $130 \mathrm{rpm}$. Verification of the $\mathrm{pH}$ during the adsorption process was made for selected samples using a $\mathrm{pH}$-meter. It remained unchanged at about 6.50, which is logical as the neutralized DTPA and APTES ligands are acting as a buffer. Desorption was tested using different concentrations of nitric acid. Practically complete desorption was achieved by shaking a sample of $100 \mathrm{mg}$ of REE-saturated particles with $20 \mathrm{~mL}$ of $1 \mathrm{M} \mathrm{HNO}_{3}$. 
Adsorption and desorption of rare earth element ions (La(III), Nd(III) and Dy(III)) on model DTPA@ $\mathrm{SiO}_{2}$ particles was evaluated by complexometric titration with EDTA in neutralized solutions using Xylenol Orange as indicator as described in our previous publication. ${ }^{49}$

\section{Synthesis of DTPA@Kromasi ${ }^{\circledR}$-derived stationary phase}

APTES-functionalized Kromasil ${ }^{\circledR}$ particles $(10 \mathrm{~g})$ and DTPA dianhydride $(7 \mathrm{~g})$ were separately dispersed in dry toluene (50 $\mathrm{mL}$ and $75 \mathrm{~mL}$, respectively) with the aid of an ultrasonic bath. Both suspensions were then combined in a reaction flask. The reaction mixture was flowed with $\mathrm{N}_{2}(\mathrm{~g})$ in a Schlenk line for some minutes before assembling the reflux setup. The reaction was carried out at $75{ }^{\circ} \mathrm{C}$ in a temperature-controlled oil bath overnight, with a condenser and under $\mathrm{N}_{2}(\mathrm{~g})$ atmosphere. After the reaction, the particles were separated by centrifugation (10 min at 10,000 $\mathrm{rpm})$ and washed twice with toluene and three times with distilled water (50 $\mathrm{mL}$ per wash).

\section{Characterization of particles}

The DTPA@ $\mathrm{SiO}_{2}$ materials were characterized morphologically using a SEM-EDS Hitachi TM1000- $\mu$-DeX environmental scanning electron microscope (SEM), a Jeol 2100 HR, 200kV transmission electron microscope (TEM), and a Bruker FastScan Bio atomic force microscope (AFM). Grafting of ligands was monitored with infrared spectroscopy (IR) using a Perkin-Elmer Spectrum 100 and with thermogravimetric analysis (TGA) using a Perkin-Elmer Pyris-1 instrument. Surface area characterization was performed by applying low temperature nitrogen sorption using a Quantachrome instrument at the ITMO University. The total carbon content of Kromasil $^{\circledR}$ particles were determined by elemental analysis using a Vario Micro cube (Elementar Analysesysteme GmbH, Germany), performed at Akzo Nobel PPC AB/Chemical Analysis Bohus, Sweden. Powder X-ray diffraction patterns of the silica nanoparticles and the Kromasil ${ }^{\circledR}$ 
microparticles were recorded using a multifunctional Bruker D8 SMART Apex-II diffractometer operating with $\mathrm{MoK} \alpha$ radiation.

\section{Column packing procedure}

DTPA functionalized mesoporous Kromasil ${ }^{\circledR}$ silica particles (AkzoNobel) with an average particle size of $10 \mu \mathrm{m}$ and an average pore diameter of $100 \AA \AA$ were packed in a 4.6 $\mathrm{mm}$ (i.d.) x $250 \mathrm{~mm}$ column. Prior to packing a slurry was prepared containing $3.5 \mathrm{~g}$ of Kromasil ${ }^{\circledR}$ particles in $20 \mathrm{~mL}$ of slurry media consisting of THF:IPA (90:10). The slurry was added to a $20 \mathrm{~mL}$ reservoir and subsequently pushed into the column using methanol ( $\geq 80 \mathrm{~mL}$ ) as push media, and with a packing pressure ramped up from 250 to $600 \mathrm{bar}$. The pressure was then immediately released, allowing the pressure over the column bed to ramp down to atmospheric pressure.

\section{HPCIC separation experiments}

A series of chromatographic separation experiments were carried out, each using a solution of equal parts of six rare earth elements, with a total $\mathrm{RE}^{3+}$ concentration in the range $1000-10,000 \mathrm{mg} \mathrm{L}^{-1}$. The elution program was conducted at flow rates between 0.5 $-1.5 \mathrm{~mL} \mathrm{~min}-1$ and at temperatures in the range $25-55^{\circ} \mathrm{C}$. Both isocratic and gradient elution procedures were used, with the concentration of $\mathrm{HNO}_{3}$ in the eluent in the range 0.10-0.24 M. A Dionex ICS $-5000^{+}$SP-5 chromatography system was used, consisting of a quaternary gradient analytical pump, a Dionex AFC-3000 fraction collector and a Dionex ICS VWD 3000 variable wavelength UV-Vis detector (all Thermo Fisher Scientific). Bottles of eluent solution were submerged in a temperature-controlled thermostatic bath (Julabo), and the temperature of the column was controlled by means of a thermostatic chamber (BIO-TEK). In order to detect REE ions, a post-column reagent (PCR) solution 
was pumped using a separate peristaltic pump (BIO-TEK), and mixed with the column effluent in a Tee-connector and a $1.0 \mathrm{~mL}$ knitted reaction coil before the detector. The PCR solution was pumped at a flow rate of $0.5 \mathrm{~mL} \mathrm{~min}^{-1}$ in all experiments. REE-Arsenazo III complexes were detected at a wavelength of $658 \mathrm{~nm}$. Sample injections were performed manually using a sample injector loop valve. Instrument control, detector data collection and rendering of chromatograms was accomplished using the software Chromeleon 7.2. The collected fractions were analyzed ex situ by inductively coupled plasma-optical emission spectroscopy (ICP-OES) using an iCAP 7400 system (Thermo Fisher Scientific). Before each run the whole system was left to stabilize thermally for 30 min while flushing the column for 15 min with a $0.3 \mathrm{M} \mathrm{HNO}_{3}$ solution followed by deionized water for another $15 \mathrm{~min}$ at a flow rate of $1 \mathrm{~mL} \mathrm{~min}^{-1}$, until the baseline was stable. A summary of the chromatographic conditions is given in Table 1.

Table 1. Parameters of the HPCIC experiments.

\begin{tabular}{|c|c|}
\hline Column & $\begin{array}{l}\text { DTPA-functionalized Kromasil }{ }^{\circledR} \text { silica } \\
(250 \mathrm{~mm} \times 4.6 \mathrm{~mm}, 10 \mu \mathrm{m} \text { particle size, } \\
100 \AA \text { porosity). }\end{array}$ \\
\hline Mobile phase & $\mathrm{HNO}_{3}$ - water \\
\hline Flow rate range & $0.5-1.5 \mathrm{~mL} \mathrm{~min}^{-1}$ \\
\hline Temperature range & $25-55^{\circ} \mathrm{C}$ \\
\hline Injected volume & 50 and $100 \mu \mathrm{L}$ \\
\hline Post column reagent (PCR) & Arsenazo III \\
\hline PCR flow rate & $0.5 \mathrm{~mL} \mathrm{~min}^{-1}$ \\
\hline
\end{tabular}




\section{RESULTS AND DISCUSSION}

\section{Characterization of DTPA@ $\mathrm{SiO}_{2}$ materials}

The methodology of DTPA grafting was investigated initially using commercial nonfunctionalized silica particles. The process was carried out as a two-step procedure, where the surface of the particles was first covered by a monolayer of APTES in an ethanol-water medium, supplying the amino functions for subsequent grafting. In the second step the ligand was attached to the pre-functionalized surface in toluene via formation of covalent amide bonds (Fig. 2).

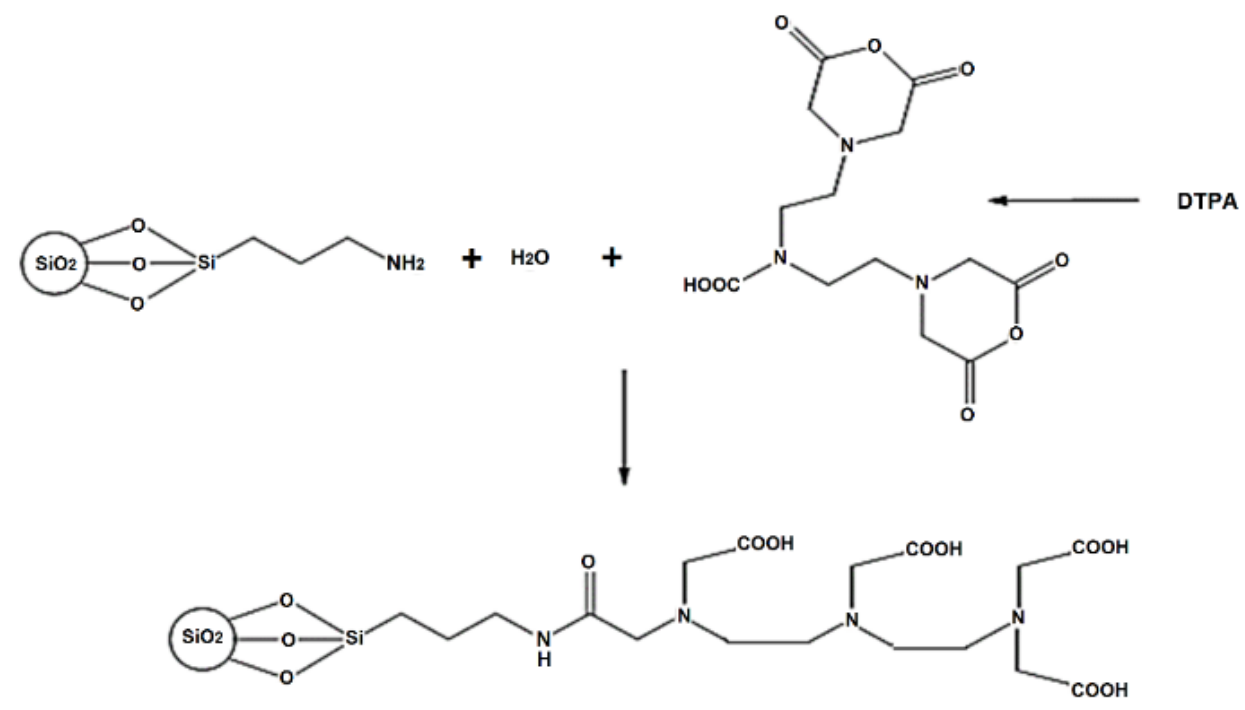

Figure 2. Grafting of DTPA anhydride on the APTES-functionalized surface.

Ligand grafting was followed by FTIR spectroscopy that for both silica and Kromasil ${ }^{\circledR}$ particles resulted in spectra closely resembling each other as well as spectra obtained for dense silica particles in our previous work ${ }^{60}$ as shown in Fig:s S3-S8 in the supplementary data. The functionalized $\mathrm{SiO}_{2}$ nanoparticles display characteristic bands of hydrated silica at $1090\left(v_{\text {as }}(\mathrm{Si}-\mathrm{O}-\mathrm{Si})\right), 950\left(\mathrm{v}_{\text {as }}(\mathrm{Si}-\mathrm{OH})\right), 800(v(\mathrm{Si}-\mathrm{O}-\mathrm{Si}))$ and $460(\delta(\mathrm{Si}-\mathrm{O}-\mathrm{Si})) \mathrm{cm}^{-1}$ and also the bands revealing presence of residual hydroxyl functions $\delta(\mathrm{O}-\mathrm{H})$ at about $1640 \mathrm{~cm}^{-}$ 
${ }^{1}$, together with protonated amine $\delta(\mathrm{N}-\mathrm{H})$ at about $1470 \mathrm{~cm}^{-1}$ (from the attached APTES function). Grafting of the amino carboxylate ligand contributes with several additional bands such as at $1728 \mathrm{~cm}^{-1}(v(\mathrm{C}=\mathrm{O})$ for carboxylic acid $)$ and about $1397 \mathrm{~cm}^{-1}(\delta(\mathrm{O}-\mathrm{H})$ of carboxylic acid). The otherwise characteristic band $v(\mathrm{C}-\mathrm{N})$ at $1250-1020 \mathrm{~cm}^{-1}$ overlaps in this case with saturated $v_{\text {as }}(\mathrm{Si}-\mathrm{O}-\mathrm{Si})$ band.

The amount of grafted ligands could be estimated by TGA. For the nanoparticles, decomposition of APTES grafted in the first step was indicated by a relatively sharp DTG peak at ca $340{ }^{\circ} \mathrm{C}$ (see Fig. S1 in the supplementary data) following after the initial evaporation of water. Both for nanoparticles and Kromasil ${ }^{\circledR}$ microparticles, the decomposition of the grafted DTPA ligand was associated with two thermal effects - a smaller weight loss at about $220{ }^{\circ} \mathrm{C}$, supposedly resulting from partial decarboxylation of grafted DTPA, and a bigger loss at $340{ }^{\circ} \mathrm{C}$, corresponding to degradation of the ligand and formation of residual carbon, later burning out at ca $600{ }^{\circ} \mathrm{C}$ (see Fig. 3 and Fig. S2 in the supplementary data). The average organic content was about 12\% - 14\% with APTES and $23 \%-26 \%$ with DTPA. The total carbon content of the Kromasil ${ }^{\circledR}$ particles before and after functionalization, respectively, as obtained by elemental analysis, was $5.72 \%$ and $17.89 \%$ by weight, respectively. This corresponds to $1.0 \mathrm{mmol} \mathrm{g}^{-1}$. As regards APTES, this result corresponds to the results from the TGA analysis. However, as regards the DTPA coverage, the elemental analysis results in a significantly higher value than the TGA

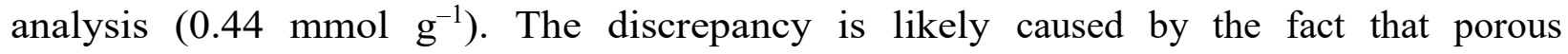
nanoadsorbents tend to contain adsorbed organic solvents, in particular after a grafting process. The TGA results have been corrected for evaporation of solvents. Based on the determined specific 
surface area of $200 \mathrm{~m}^{2} \mathrm{~g}^{-1}$ of the DTPA-functionalized particles, the estimated ligand coverage is $1.5 \mu \mathrm{mol} \mathrm{m}^{-2}$.

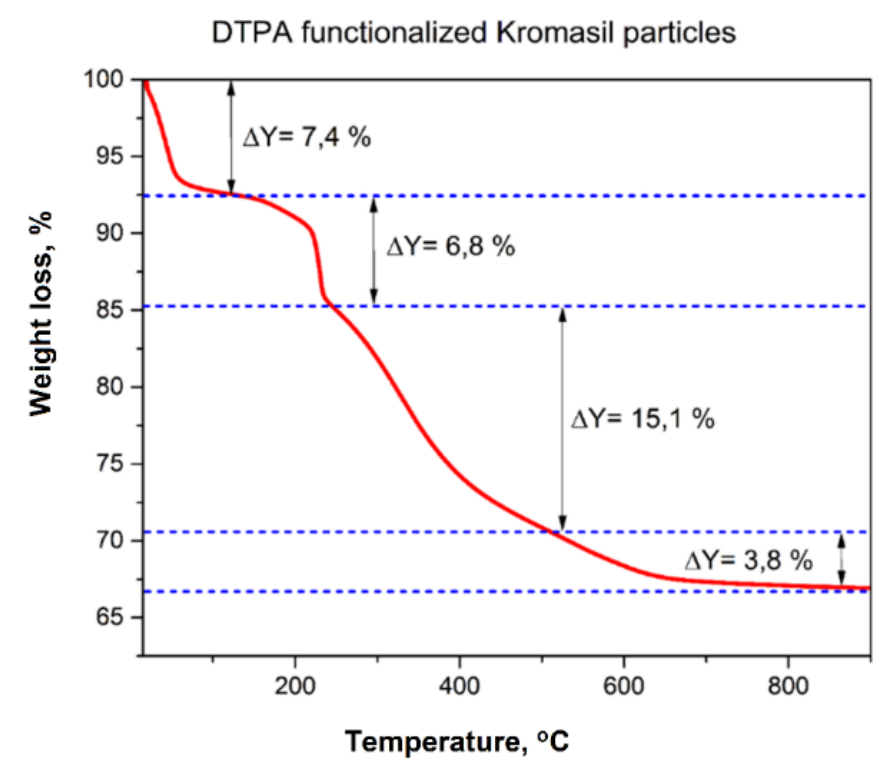

Figure 3. TGA trace of the DTPA-functionalized Kromasi $1^{\circledR}$ microparticles.

Fig. 4 shows SEM and AFM analyses of the $\operatorname{Kromasil}^{\circledR}$ particles before and after DTPAfunctionalization. In SEM the particles appear as relatively uniform, rather smooth spheres (Fig. 4 A, B). Grafting of the ligands does not change the appearance of the Kromasil ${ }^{\circledR}$ particles. The structure of the Kromasil ${ }^{\circledR}$ particles was visualized using AFM. The particles possess a hierarchical structure built up of blocks with a diameter of about 20-30 nm (Fig. 4 C-F). The blocks are packed quite densely together on the surface of the particles and reveal almost as dense a packing in the cross-cut. The smaller blocks are apparently also porous as the surface area of Kromasil ${ }^{\circledR}$ is quite large, $263 \mathrm{~m}^{2} \mathrm{~g}^{-1}$ with a pore volume of $0.686 \mathrm{~cm}^{3} \mathrm{~g}^{-1}$, while the pore size of $5.6 \mathrm{~nm}$ is relatively small for a packing of $20-30 \mathrm{~nm}$ blocks. The modification of the Kromasil ${ }^{\circledR}$ microparticles by DTPA results apparently in formation of a monolayer of grafted ligand as indicated by the combined TGA, FTIR and 
AFM results. No change in their appearance could be observed either with SEM or AFM at any available magnification. The observed changes in surface area and pore volume are also in agreement with this assumption $\left(200 \mathrm{~m}^{2} \mathrm{~g}^{-1} ; 0.487 \mathrm{~cm}^{3} \mathrm{~g}^{-1}\right.$; average pore size 5.6 $\mathrm{nm}$ - almost the same as before modification).
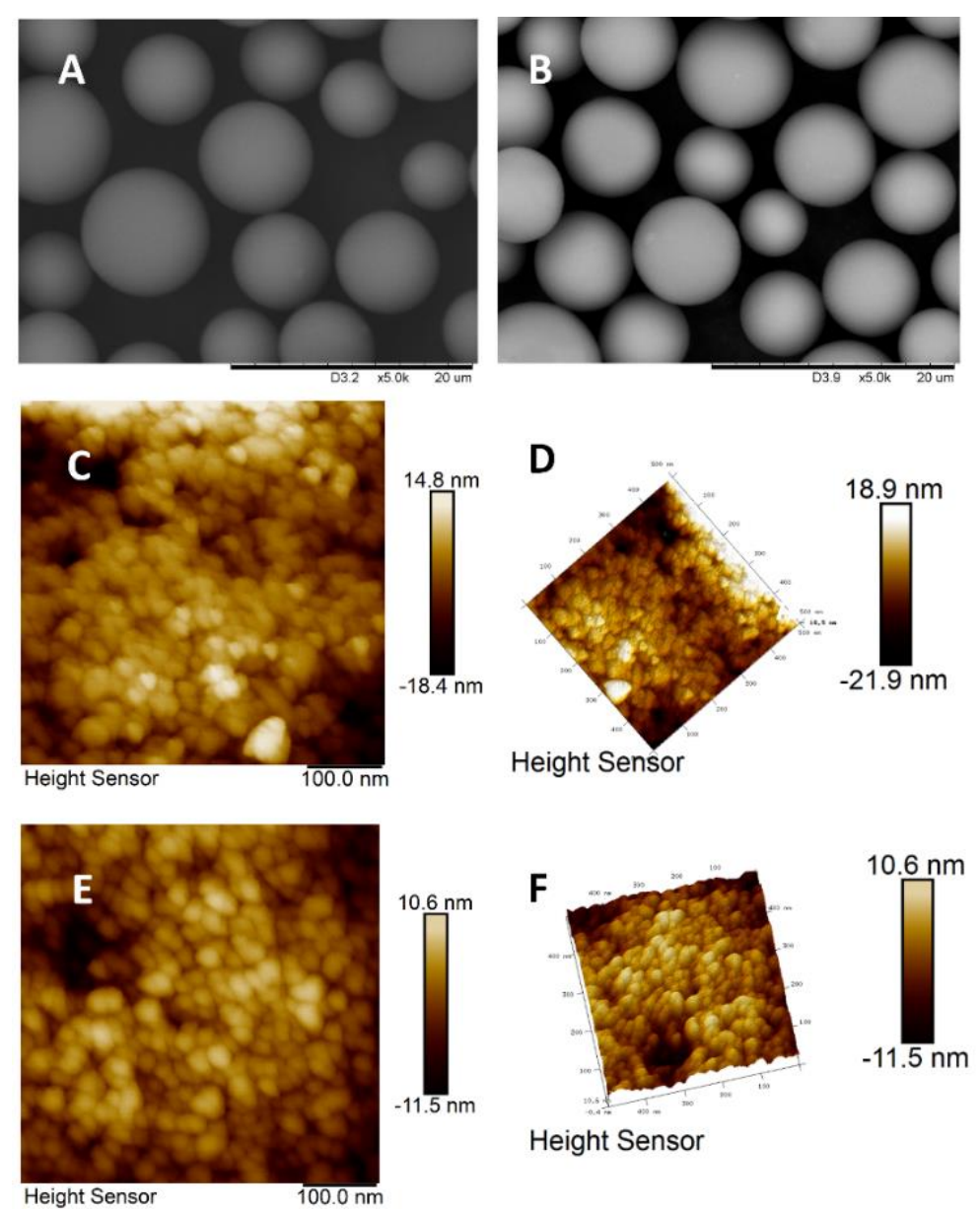

Figure 4. SEM (A-B) and AFM (C-F) of the Kromasil ${ }^{\circledR}$ microparticles (A, C and D -pure particles; B, E and F - particles after functionalization by DTPA).

Based on a large number of collected TEM images, it is concluded that the same preservation of the morphology and particle size was observed for the $\mathrm{SiO}_{2}$ nanoparticles throughout the whole grafting process (Fig. 5; pore structure and pore size distributions are provided in Table S1 of the supplementary data). The particles, with an average size of 
about $20 \mathrm{~nm}$, are aggregated in the form of randomly cross-linked chains. Their appearance in TEM remains unchanged after attachment of APTES followed by grafting of DTPA. Moreover, no visible change in particle size or morphology was observed after REE sorption and subsequent release in acidic medium, nor after further treatment at lower $\mathrm{pH}$. However, on grafting the color of the particles, nanoparticles as well as Kromasil ${ }^{\circledR}$, was observed to change slightly from their original white to a pale color.

The kinetics of REE cation uptake investigated in the dynamic regime demonstrated for both mesoporous $\mathrm{SiO}_{2}$ and Kromasil particles that almost full capacity could be achieved within just a few minutes (see Fig. S9). The total capacity of the DTPA modified $20 \mathrm{~nm}$ $\mathrm{SiO}_{2}$ particles towards single REE cations was rather high in the range $0.89-0.95 \mathrm{mmol} \mathrm{g}^{-}$ ${ }^{1}$ (see Fig. 6). The $q_{\max }$ values were calculated by fitting the coefficients of the Langmuir equation to the isotherms, see Fig. S11 in the supplementary data. The selectivity studies in 3-component mixtures (Fig. S6) showed that the mesoporous silica displayed appreciably lower capacity for mixtures than for the individual REEs, indicating that they are forming different kinds of complexes, which agrees with the literature data on the complexation with amino carboxylate ligands. ${ }^{37}$ 

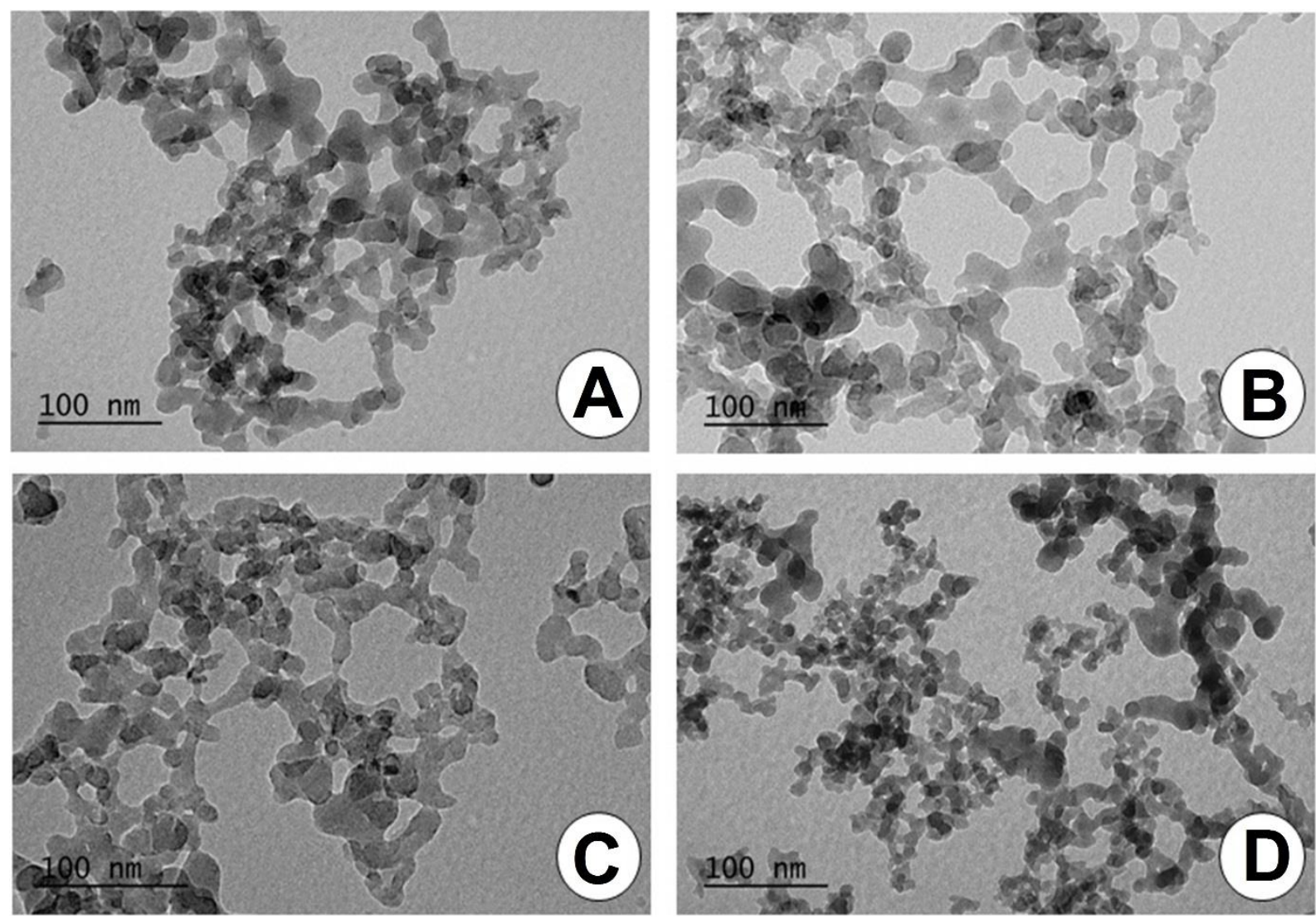

Figure 5. Transmission electron microscopy images of (A) initially functionalized hybrid $\mathrm{SiO}_{2}$ particles, (B) hybrid particles with adsorbed $\mathrm{La}(\mathrm{III}), \mathrm{Dy}(\mathrm{III})$ and $\mathrm{Nd}(\mathrm{III})$, (C) acidtreated $(\mathrm{pH}=1.9)$ hybrid particles, and (D) further acid-treated $(\mathrm{pH}=1.3)$ hybrid particles.

The desorption was over $93 \%$ (in the range $93 \%-98 \%$ as an average of at least 3 titrations in 3 independent experiments) for particles washed with $1 \mathrm{M} \mathrm{HNO}_{3}$ as determined by complexometric titration of the produced supernatant. The near-complete desorption was also clearly testified by EDS analysis (see Fig. S13 in the Electronic supplementary). Appreciable selectivity could be observed, especially on desorption with solutions of lower acidity $(\mathrm{pH}=3-3.5)$, demonstrating easier release of lighter REEs. It is worth mentioning that, even under such acidic conditions, silica particles have been shown to be stable. ${ }^{60}$ 

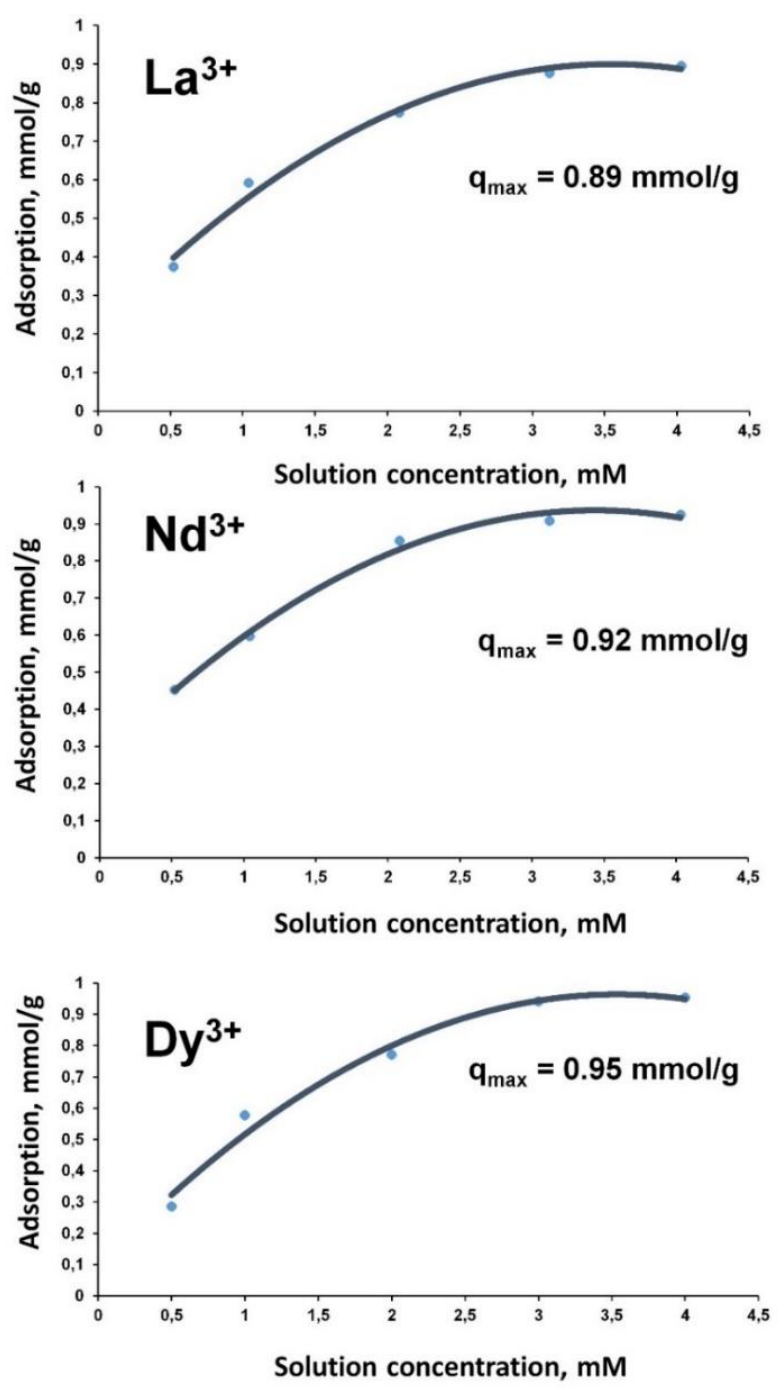

Figure 6. Adsorption isotherms for $\mathrm{La}(\mathrm{III}), \mathrm{Nd}(\mathrm{III})$ and $\mathrm{Dy}(\mathrm{III})$ cations by APTES and DTPA modified $20 \mathrm{~nm} \mathrm{SiO}_{2}$ particles.

\section{Separation of REEs with DTPA using HPCIC}

\section{Isocratic and gradient elution}

Generally in HPCIC, isocratic elution has the advantage over gradient elution of robustness and easy, straightforward application, in particular for industrial scale processes. Several isocratic experiments were carried out with varying levels of eluent $\mathrm{HNO}_{3}$ concentration $(0.1 \mathrm{M}-0.24 \mathrm{M})$ with a total elution time of $15 \mathrm{~min}$, and with flow rate and 
column temperature kept constant at $1 \mathrm{~mL} \min ^{-1}$ and $55{ }^{\circ} \mathrm{C}$, respectively. The chromatograms in Fig. 7 A show that, under the evaluated conditions, isocratic elution did not lead to separation of the six REEs studied.

Linear gradient elution was investigated, with the eluent $\mathrm{HNO}_{3}$ concentration increasing linearly from zero to a final value in the range $0.1 \mathrm{M}-0.24 \mathrm{M}$. The column temperature was kept constant at $55^{\circ} \mathrm{C}$ and the mobile phase flow rate at $1 \mathrm{~mL} \mathrm{~min}{ }^{-1}$. As shown by the chromatograms in Fig. 7 B, a good overall separation could be achieved using relatively low $\mathrm{HNO}_{3}$ concentrations. In all runs, Y(III) partially co-eluted with $\mathrm{Nd}(\mathrm{III})$ before Dy(III) and this separation was incomplete.

The degree of protonation of the functional groups of the chelating agent molecules depends on the concentration of acid in the eluent. Hence, a very small change in the eluent acid concentration $\left(0.1 \mathrm{M}-0.24 \mathrm{M} \mathrm{HNO}_{3}\right)$ is expected to result in a significant change in the retention factor $\left(k^{\prime}\right)$ of $\mathrm{RE}^{3+}$ due to the variation in the electrostatic interactions between the separated $\mathrm{RE}^{3+}$ ions and the functional groups of the chelating agent. The affinity of the DTPA@ Kromasil ${ }^{\circledR}$ column for $\mathrm{RE}^{3+}$ ions increases in the order $\mathrm{La}(\mathrm{III})<\mathrm{Ce}(\mathrm{III})<\operatorname{Pr}(\mathrm{III})<$ $\mathrm{Nd}(\mathrm{III})<\mathrm{Y}(\mathrm{III})<\mathrm{Dy}(\mathrm{III})$, due to the decrease in ionic radius of the $\mathrm{RE}^{3+}$ ions. This matches the reported stability constant between the $\mathrm{RE}^{3+}$ ions and DTPA. ${ }^{59}$ 

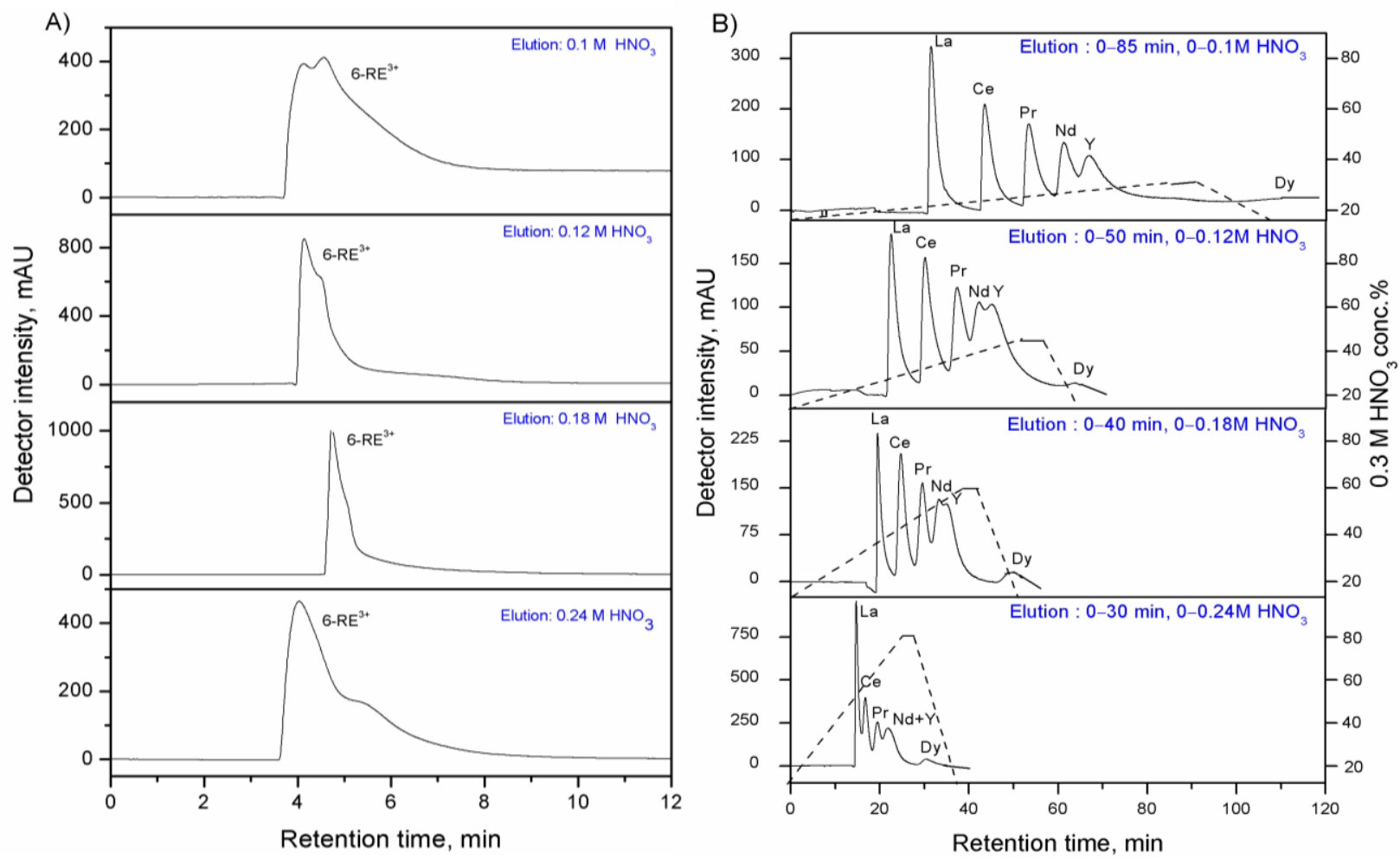

Figure 7. Chromatograms from A) isocratic and B) linear gradient elution studies at different concentration of $\mathrm{HNO}_{3}$ in the eluent. Eluent flow rate $=1 \mathrm{~mL} \mathrm{~min}{ }^{-1}$, column temperature $=55^{\circ} \mathrm{C}$, injected volume $=50 \mu \mathrm{L}$, and total REE concentration $=1000 \mathrm{mg} \mathrm{L}^{-1}$.

\section{Influence of column temperature}

It has previously been documented that the column temperature can have a significant effect on both the retention and the separation of metal ions in HPCIC. ${ }^{61}$ A higher temperature will also reduce the pressure drop over the column. The effect of temperature on the retention and $\mathrm{RE}^{3+}$ separation was investigated by varying the column temperature in the range $25^{\circ} \mathrm{C}-55^{\circ} \mathrm{C}$, while keeping the eluent linear gradient profile (from $0 \mathrm{M}-$ $0.15 \mathrm{M} \mathrm{HNO}_{3}$ over $\left.55 \mathrm{~min}\right)$ and flow rate $\left(1 \mathrm{~mL} \mathrm{~min}^{-1}\right)$ unchanged. The corresponding chromatograms are shown in Fig. 8, and the retention factors $\left(k^{\prime}\right)$ and separation factors between adjacent REE pairs $\left(\alpha_{\mathrm{A} / \mathrm{B}}\right)$ are given in Table 2. Although the latter show a 
noticeably minor dependence on temperature, the overall peak resolution improves with temperature. At $25{ }^{\circ} \mathrm{C}$ only a rudimentary separation was achieved with the evaluated column, flow rate and gradient, while at $55^{\circ} \mathrm{C}$ good separation of $\mathrm{La}(\mathrm{III}), \mathrm{Ce}(\mathrm{III}), \operatorname{Pr}(\mathrm{III})$ and Dy(III) ions was achieved, while Y(III) partially co-eluted with $\mathrm{Nd}(\mathrm{III})$ ions. Clearly, the improvement in resolution with temperature is related to an increased column efficiency.

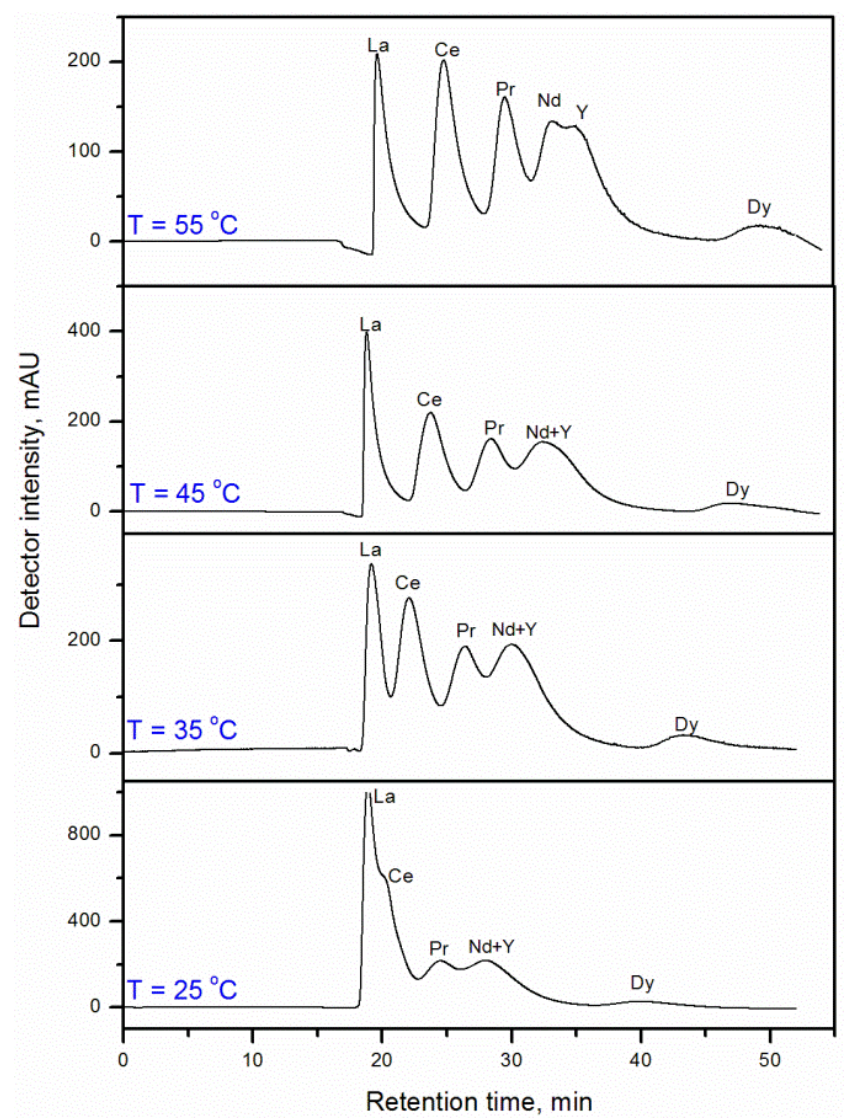

Figure 8. Chromatograms obtained at different column temperatures, for linear gradient elution experiments (from $0 \mathrm{M}-0.15 \mathrm{M} \mathrm{HNO}_{3}$ over $55 \mathrm{~min}$ ). Eluent flow rate $=1 \mathrm{~mL} \mathrm{~min}{ }^{-1}$, injected volume $=50 \mu \mathrm{L}$, and total REE concentration $=1000 \mathrm{mg} \mathrm{L}^{-1}$. 
Table 2. Retention factor $\left(k^{\prime}\right)^{*}$ and separation factor $\left(\alpha_{\mathrm{A} / \mathrm{B}}\right)^{*}$ for six REEs obtained at different temperatures. Chromatographic conditions: gradient elution experiments (from $0 \mathrm{M}-0.15 \mathrm{M}$ $\mathrm{HNO}_{3}$ over $55 \mathrm{~min}$ ), eluent flow rate $=1 \mathrm{~mL} \mathrm{~min}{ }^{-1}$, injected volume $=50 \mu \mathrm{L}$, and total REE concentration $=1000 \mathrm{mg} \mathrm{L}^{-1}$.

\begin{tabular}{|c|c|c|c|c|c|c|c|c|}
\hline & \multicolumn{2}{|r|}{$55^{\circ} \mathrm{C}$} & \multicolumn{2}{|c|}{$45^{\circ} \mathrm{C}$} & \multicolumn{2}{|c|}{$35^{\circ} \mathrm{C}$} & \multicolumn{2}{|r|}{$25^{\circ} \mathrm{C}$} \\
\hline & $k^{\prime}$ & $\alpha_{\text {pair }}$ & $\mathrm{k}^{\prime}$ & $\alpha_{\text {pair }}$ & $k^{\prime}$ & $\alpha_{\text {pair }}$ & $k^{\prime}$ & $\alpha_{\text {pair }}$ \\
\hline La & 4.9 & ---- & 4.6 & ---- & 4.7 & ------ & 4.7 & ------ \\
\hline $\mathrm{Ce}$ & 6.5 & $\mathrm{La} / \mathrm{Ce}=1.3$ & 6.2 & $\mathrm{La} / \mathrm{Ce}=1.3$ & 5.7 & $\mathrm{La} / \mathrm{Ce}=1.2$ & 5.08 & $\mathrm{La} / \mathrm{Ce}=1.08$ \\
\hline Pr & 8.0 & $\mathrm{Ce} / \mathrm{Pr}=1.23$ & 7.6 & $\mathrm{Ce} / \mathrm{Pr}=1.23$ & 7.03 & $\mathrm{Ce} / \mathrm{Pr}=1.23$ & 6.34 & $\mathrm{Ce} / \mathrm{Pr}=1.24$ \\
\hline Nd & 9.1 & $\mathrm{Pr} / \mathrm{Nd}=1.13$ & 9.0 & $\mathrm{Pr} / \mathrm{Nd}=1.18$ & 8.17 & $\mathrm{Pr} / \mathrm{Nd}=1.16$ & 7.5 & $\mathrm{Pr} / \mathrm{Nd}=1.18$ \\
\hline $\mathbf{Y}$ & 9.7 & $\mathrm{Nd} / \mathrm{Y}=1.07$ & 9.0 & $\mathrm{Nd} / \mathrm{Y}=1$ & 8.17 & $\mathrm{Nd} / \mathrm{Y}=1$ & 7.5 & $\mathrm{Nd} / \mathrm{Y}=1$ \\
\hline Dy & 14.1 & $\mathrm{Y} / \mathrm{Dy}=1.46$ & 13.6 & $\mathrm{Y} / \mathrm{Dy}=1.5$ & 12.3 & $\mathrm{Y} / \mathrm{Dy}=1.5$ & 11.3 & $\mathrm{Y} / \mathrm{Dy}=1.5$ \\
\hline
\end{tabular}

*Retention factors and separation factors calculated using $k^{\prime}=\left(t_{\mathrm{R}}-t_{0}\right) / t_{\mathrm{o}}$ and $\alpha_{\mathrm{A} / \mathrm{B}}=k_{\mathrm{B}}^{\prime} / k_{\mathrm{A}}^{\prime}$, respectively. $t_{R}$ is the retention time of the analyte in the column and $t_{\mathrm{o}}$ is the mobile phase retention time in the column (void time). Both $t_{\mathrm{R}}$ and $t_{\mathrm{o}}$ have been corrected for extra column void volumes.

\section{Column efficiency and long-term stability}

The efficiency of a column is measured as the height of a theoretical plate (HETP), which for a column of a given length $(L)$ results in a number of plates $(N)$ equal to $L /$ HETP. For an efficient separation between adjacent peaks, the band broadening - and hence the HETP - should be as low as possible. As given by the van Deemter equation, the efficiency depends on the flow rate, with a minimum in HETP at some optimum value. The effect of the eluent flow rate in the range $0.5-$ $1.5 \mathrm{~mL} \min ^{-1}$ on the HETP, calculated using equation (1), as well as the retention factor was evaluated for La, Ce, Pr, Nd, Y and Dy for a linear gradient elution ( $0 \mathrm{M}-0.15 \mathrm{M} \mathrm{HNO}_{3}$ over 55 min) at a temperature of $55^{\circ} \mathrm{C}$. 


$$
\mathrm{HETP}=\frac{\boldsymbol{L}}{\mathbf{1 6}}\left(\frac{\boldsymbol{W}}{\boldsymbol{t}_{\boldsymbol{R}}}\right)^{2}
$$

$W$ is the peak width $\left(\Delta t_{\mathrm{w}}\right)$. Fig. 9 shows that, with some difference between the different

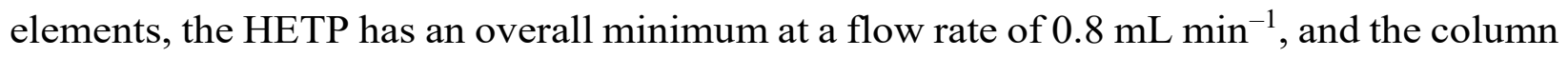
efficiency for all the evaluated REEs decreases with increasing flow rate above this value. The HETP values at the lowest flow rate for the different $\mathrm{RE}^{3+}$ ions range from $0.6 \mu \mathrm{m}$ to $20 \mu \mathrm{m}$, leading to $N$ ranging from 12,000 to $400,000 \mathrm{~m}^{-1}$. The corresponding chromatograms are shown in Fig. 10. As illustrated in the figure, the best resolution was obtained for the two intermediate flow rates, while the highest flow rate led to a somewhat shorter cycle at the cost of a lower resolution.

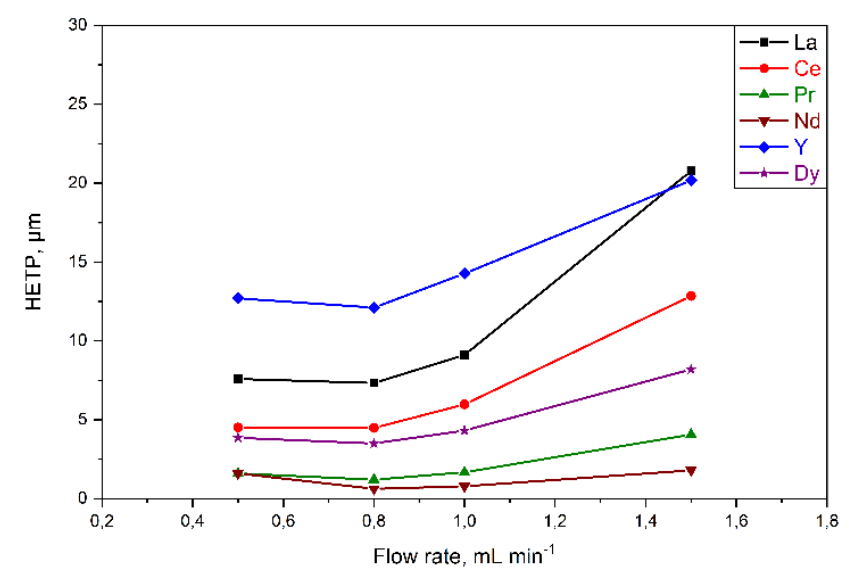

Figure 9. Effect of eluent flow rate on peak efficiency (HETP) for $\mathrm{La}(\mathrm{III}), \mathrm{Ce}(\mathrm{III}), \mathrm{Pr}(\mathrm{III}), \mathrm{Nd}(\mathrm{III})$, Y(III) and Dy(III) ions, for linear gradient elution experiments (from $0 \mathrm{M}-0.15 \mathrm{M} \mathrm{HNO}_{3}$ over 55 min). Column temperature $=55^{\circ} \mathrm{C}$, injected volume $=50 \mu \mathrm{L}$, and total REE concentration $=1000$ $\mathrm{mg} \mathrm{L} \mathrm{L}^{-1}$. 


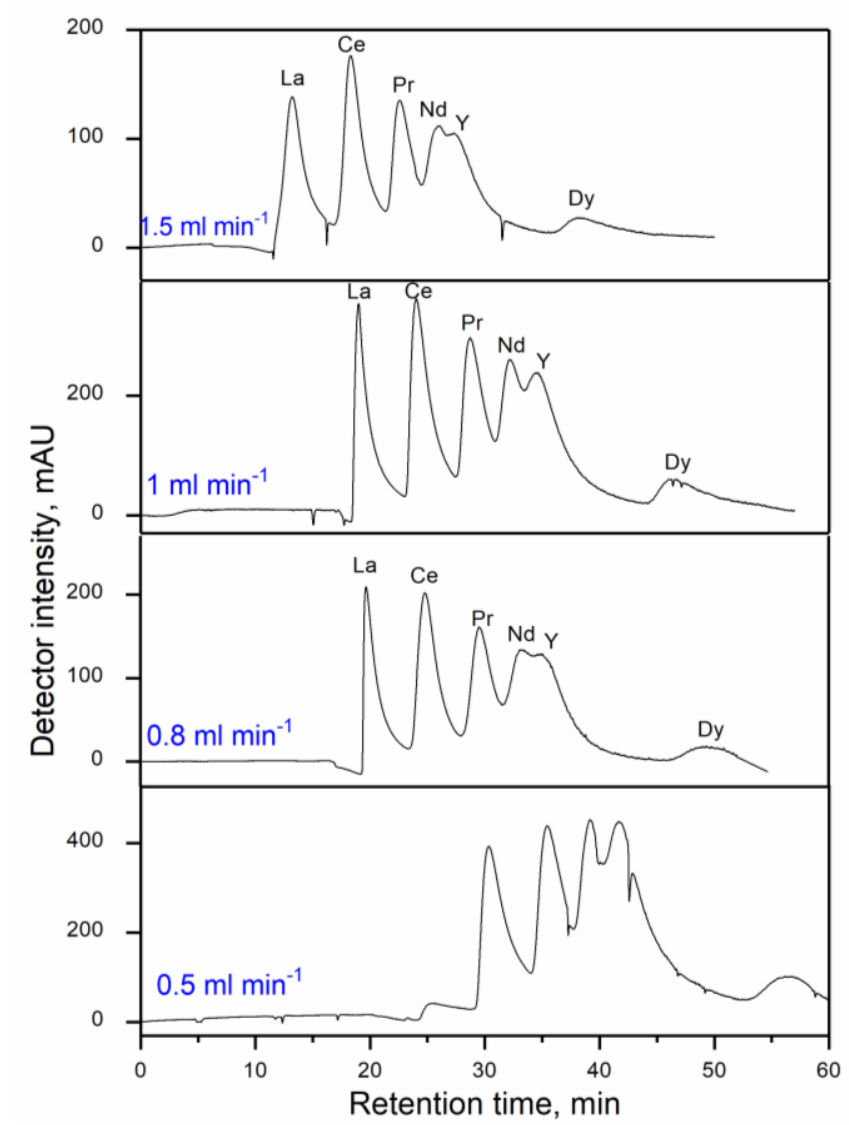

Figure 10. Chromatograms obtained at different flow rates, for linear gradient elution experiments (from $0 \mathrm{M}-0.15 \mathrm{M} \mathrm{HNO}_{3}$ over $55 \mathrm{~min}$ ). Column temperature $=55^{\circ} \mathrm{C}$, injected volume $=50 \mu \mathrm{L}$, and total REE concentration $=1000 \mathrm{mg} \mathrm{L}^{-1}$.

In theory, the column efficiency can be increased by reducing the particle size, due to reduced diffusion and faster mass transfer. However, the pressure drop over a packed column is inversely proportional to the square of the particle diameter. Hence, a reduction in particle size can rapidly lead to requirements on the pump pressure which can be prohibitive in a chromatographic process intended to be scaled up.

The long-term stability of the DTPA@Kromasil ${ }^{\circledR}$ column was evaluated by comparing the change in retention times of $\mathrm{RE}^{3+}$ ions after 54 experimental runs. The experimental conditions of the compared runs are identical; linear gradient elution $(0 \mathrm{M}-0.15 \mathrm{M}$ over 
$55 \mathrm{~min}$ ), eluent flow rate $=1 \mathrm{~mL} \min ^{-1}$ and column temperature $=55{ }^{\circ} \mathrm{C}$. Only a minor deterioration in the column performance was recorded after 54 runs, with the peak positions somewhat shifted towards lower retention times (average reduction in retention time $=2 \%$ ), as shown in Fig. 11. It is important to mention that the covalent grafting applied in this case represents a principal advantage compared to earlier proposed impregnation of silica with a polymer ligand (see Ref. 44) as no measurable organic ligand leakage could be detected in this case. This is very logical in the view generally recognized of stability of carbonylamide (peptide) bond in neutral and acidic environment. ${ }^{62}$

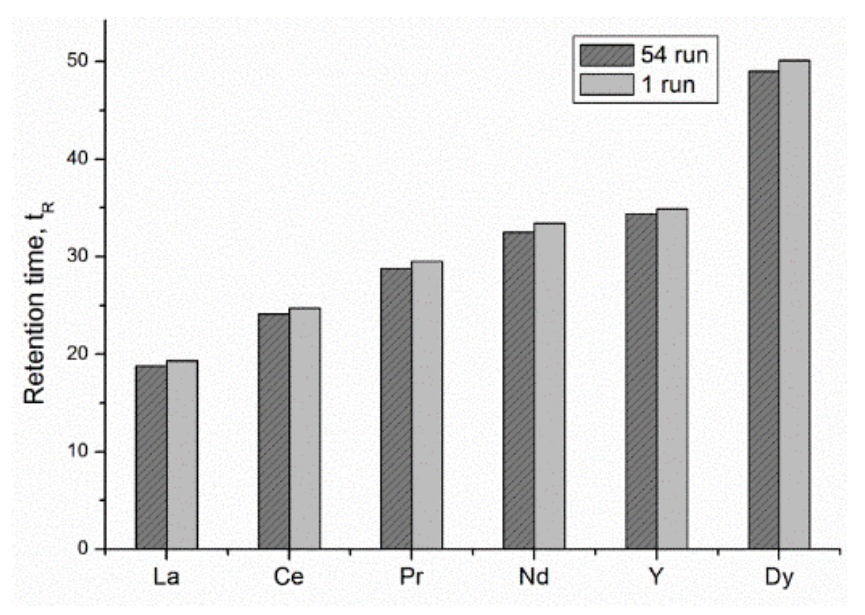

Figure 11. Comparison of retention times obtained for the six REEs with a freshly packed column and after 54 experimental runs.

In Table 3, the optimum experimental conditions and the highest obtained column efficiency are compared against previously reported work on HPCIC separation of rare earth elements. The results show that the DTPA@Kromasil ${ }^{\circledR}$ column compares favorably with similar studies, with a relatively high efficiency obtained considering the moderate temperature and pressure drop. In addition, the column exhibits a promising long-term stability, which is important for the overall process economy in industrial applications. 
Table 3. Experimental parameters and column efficiency for HPCIC separation of rare earth elements reported in the literature compared with the present work.

\begin{tabular}{|c|c|c|c|c|}
\hline Column specifications & $\begin{array}{c}\text { Material and } \\
\text { particle size }\end{array}$ & $\begin{array}{l}\text { Temperature } \\
\text { ('C) }\end{array}$ & $\begin{array}{l}\text { Flow rate } \\
\left(\mathrm{mL} \text { min }^{-1}\right)\end{array}$ & $\begin{array}{l}\text { Efficiency } \\
, N\left(\mathbf{m}^{-1}\right)\end{array}$ \\
\hline $\begin{array}{l}\text { NTAgel } \\
\text { functionalized } \\
\text { macroporous } \\
\text { hydrophilic } \\
\text { resin column } \\
\end{array}$ & $\begin{array}{c}\text { GMAgel } \\
\text { polymer resin } \\
(10 \mu \mathrm{m})\end{array}$ & 40 & 1.0 & $\begin{array}{l}\text { Not } \\
\text { reported }\end{array}$ \\
\hline $\begin{array}{l}\text { IDA modified } \\
\text { silica column }^{30}\end{array} \quad(250 \times 4 \mathrm{~mm})$ & $\begin{array}{c}\text { Silica } \\
\text { particles } \\
(6 \mu \mathrm{m})\end{array}$ & 65 & 0.8 & 12,000 \\
\hline $\begin{array}{ll}\text { HEIDA } & \\
\text { modified } & \begin{array}{l}\text { core- } \\
\text { silica }\end{array} \\
\text { shell } & (50 \times 2.1 \mathrm{~mm}) \\
\text { column } & \end{array}$ & $\begin{array}{l}\text { Core-shell } \\
\text { Silica } \\
\text { particles } \\
(1.7 \mu \mathrm{m})\end{array}$ & 70 & 0.8 & 200,000 \\
\hline $\begin{array}{l}\text { DTPA } \\
\text { functionalized } \\
\text { Kromasil }^{\circledR} \text { silica } \quad(250 \times 4.6 \mathrm{~mm}) \\
\text { column } \\
\text { (present work) }\end{array}$ & $\begin{array}{l}\text { Kromasil }^{\circledR} \\
\text { silica } \\
\text { particles } \\
(10 \mu \mathrm{m})\end{array}$ & 55 & 1.0 & 400,000 \\
\hline
\end{tabular}

\section{Column overloading}

In order for a chromatographic process to be viable economically on an industrial scale, a sufficiently high productivity for a given degree of separation is necessary. Accordingly, the response of the chromatographic process to increased sample load was investigated in a series of experiments with increasing REE concentration and injected volume. The total REE concentration was in the range of $1000 \mathrm{ppm}$ to $10,000 \mathrm{ppm}$, and the injected volume was $50 \mu \mathrm{L}$ or $100 \mu \mathrm{L}$. All other experimental conditions were kept constant (linear gradient elution ( $0 \mathrm{M}-0.15 \mathrm{M}$ over $55 \mathrm{~min})$, eluent flow rate $=1 \mathrm{~mL} \mathrm{~min}^{-1}$, and column temperature 
$=55{ }^{\circ} \mathrm{C}$ ). The resulting chromatograms are presented in Fig. $12 \mathrm{~A}$ together with ICP analyses of the fractions collected at REE loads of $0.5 \mathrm{mg}$ and $1.0 \mathrm{mg}$.

For total REE loads between $0.05 \mathrm{mg}$ and $0.25 \mathrm{mg}$ the chromatograms exhibit very small differences; the peaks appear at similar retention times and are quite similar in shape, and the REEs are overall well separated. The chromatogram obtained at a total REE load of 0.5 mg is distinctly different, however, with peak displacement, and triangular peak shapes characteristic of column overloading. As can be seen in the corresponding ICP graph, however, the separation between most of the REEs is still satisfactory. Nd and Pr are almost completely separated, and the major issue is that $\mathrm{Y}$ partly coelutes with $\mathrm{Nd}$. At twice the load, $1.0 \mathrm{mg}$, the chromatogram is even further distorted, and the ICP analysis reveals that the overall separation is now severely compromised. In particular, the resolution between $\mathrm{La}, \mathrm{Ce}, \mathrm{Pr}$, and Nd is now much worse, while Dy is still largely separated from the other elements. With this column and under the evaluated conditions, it is clear that an optimum in productivity will be located at a total REE load of somewhere between $0.25 \mathrm{mg}$ and 0.50 mg per cycle. Scaled up to a $50 \mathrm{~mm}$ diameter pilot-scale column and to a $1.2 \mathrm{~m}$ diameter industrial scale column, this translates into up to $59 \mathrm{mg}$ and $34 \mathrm{~g}$ per cycle, respectively. The maximum productivity could likely be pushed somewhat further by tuning the experimental conditions, but in order to really improve the separation power at high sample load it would be desirable to increase the ligand coverage. 

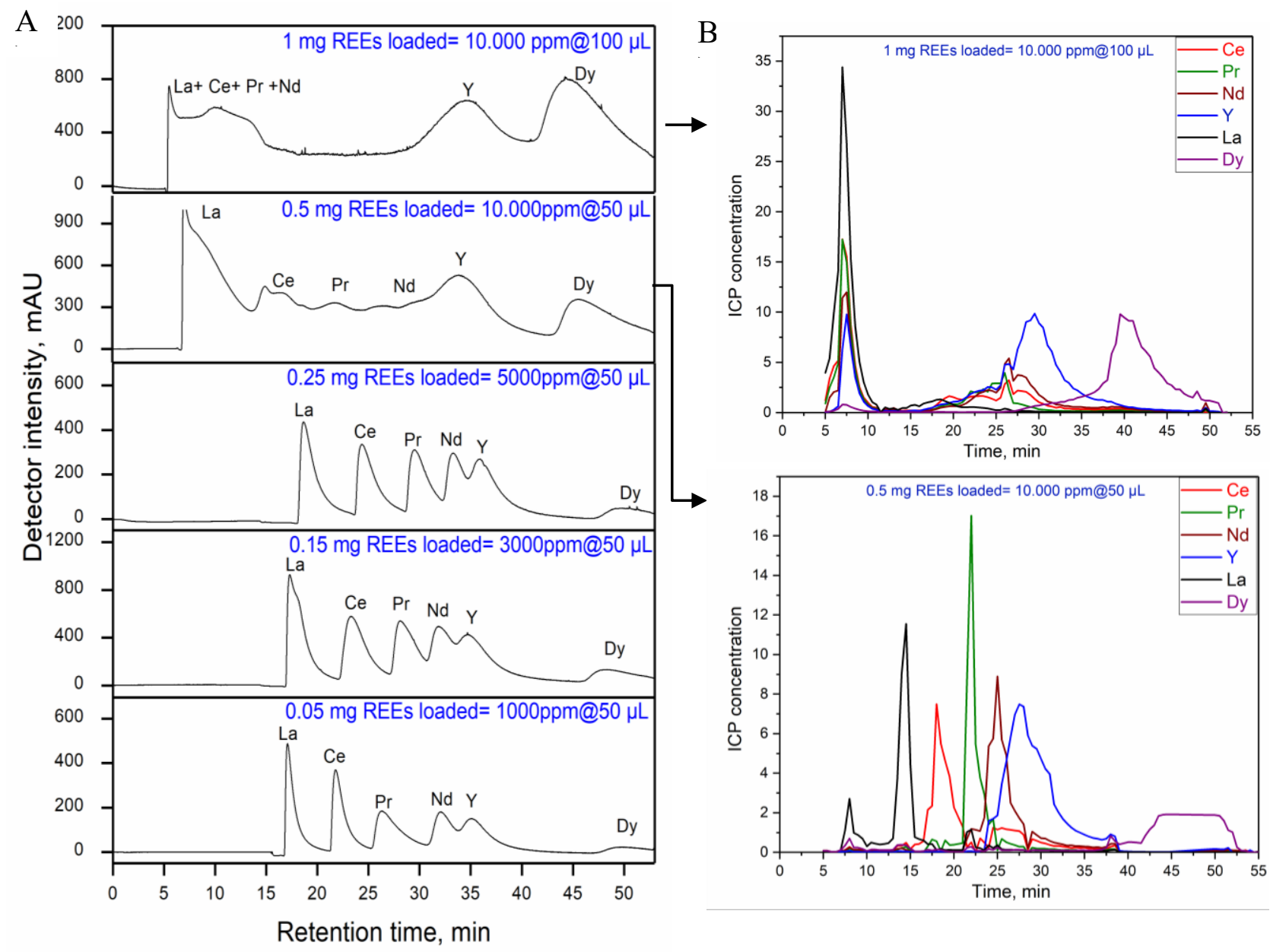

Figure 12. A) Chromatograms of experiments with increasing sample load, with linear gradient elution ( $0 \mathrm{M}-0.15 \mathrm{M} \mathrm{HNO}_{3}$ over $\left.55 \mathrm{~min}\right)$, eluent flow rate $=1 \mathrm{~mL} \mathrm{~min}{ }^{-1}$, and column temperature $\left.=55^{\circ} \mathrm{C}\right)$. B) ICP element-resolved fraction analysis of experiments with the highest total sample loads.

\section{CONCLUSIONS}

$20 \mathrm{~nm}$ silica nanoparticles and Kromasil ${ }^{\circledR}$ microparticles functionalized with DTPA have been produced and fully characterized, and evaluated with respect to the amount of grafted ligand and the capacity to adsorb REE ions. Both types of materials are shown to be efficient adsorbents with maximum capacities up to almost $1.0 \mathrm{mmol}^{-1} \mathrm{REE}$, and revealing a potential selectivity for REE separation. Functionalized Kromasil ${ }^{\circledR}$ particles 
have been evaluated as a novel packing material for separation of REE ions using HPCIC. Using a 4.6 x $250 \mathrm{~mm}$ lab-scale column, separation of La(III), Ce(III), $\operatorname{Pr}(\mathrm{III}), \mathrm{Nd}(\mathrm{III})$ and Dy(III) was achieved using a linear gradient elution from $0 \mathrm{M}$ to $0.15 \mathrm{M} \mathrm{HNO}_{3}$ over 55 min with an eluent flow rate of $1 \mathrm{~mL} \min ^{-1}$ and a column temperature of $55^{\circ} \mathrm{C}$, up to a total load of $0.5 \mathrm{mg}$ REE. Y(III) partially co-eluted with Nd(III) in all experiments. The DTPA functionalized column has been verified to provide reproducible separations for at least 54 runs. Overall, it is shown that the evaluated system has a signification potential for use in preparative chromatographic separation of REEs in an environmentally sustainable alternative to liquid-liquid extraction, either on its own or as a complement to other processes.

\section{ASSOCIATED CONTENT}

\section{Supporting Information}

The supporting information is available free of charge on the ACS publication website at http://pubs.acs.org.

TGA measurements of APTES-functionalized $20 \mathrm{~nm}$ silica nanoparticles and APTESfunctionalized and DTPA-grafted $20 \mathrm{~nm}$ silica nanoparticles; FTIR spectrum of the DTPA alone, applied $20 \mathrm{~nm}$ silica nanoparticles alone, APTES-DTPA modified $20 \mathrm{~nm}$ silica nanoparticles, and APTES-DTPA modified $20 \mathrm{~nm}$ silica nanoparticles after uptake of $\mathrm{La}^{3+}, \mathrm{Nd}^{3+}$ and $\mathrm{Dy}^{3+}$ respectively; Kinetics of REE uptake by modified $20 \mathrm{~nm}$ silica nanoparticles, for Dy and for a 1:1:1 mixture of $\mathrm{La}+\mathrm{Dy}+\mathrm{Nd}$, respectively; Relative uptake of cations from a 3-component mixture by modified $20 \mathrm{~nm}$ silica nanoparticles; Linearized presentation of Langmuir isotherms and their fitting with statistical parameters and binding constants; PXRD patterns of $20 \mathrm{~nm}$ silica 
nanoparticles and Kromasil silica microparticles, and pore size distribution for $\mathrm{SiO}_{2}$-DTPA material calculated using the $\mathrm{BJH}$ method.

\section{AUTHOR INFORMATION}

\section{Corresponding Author}

*Åke C. Rasmuson.

E-mail: akera@kth.se

\section{Funding Sources}

This work was financially supported by the Swedish Foundation for Strategic Research (SSF), grant IRT 11-0026, and by the FP-7 EU Program grant 309373 "Development of a Sustainable Exploitation Scheme for Europe's Rare Earth Deposits" (EURARE). (Project web site: www.eurare.eu. This publication reflects only the authors' view, exempting the Community from any liability).

\section{Notes}

The authors declare no competing financial interest.

\section{ACKNOWLEDGMENT}

The authors would like to express their gratitude to Mr. Arnaud Duperron for the help in the synthesis and characterization of functional silica.

\section{REFERENCES}

1. Haque, N.; Hughes, A.; Lim, S.; Vernon, C., Rare earth elements: Overview of mining, mineralogy, uses, sustainability and environmental impact. Resources 2014, 3 (4), 614-635.

2. Müller, M. A.; Schweizer, D.; Seiler, V., Wealth effects of rare earth prices and China's rare earth elements policy. J. Bus. Ethics. 2016, 138 (4), 627-648.

3. Liu, J.-f.; Vora, P.; Walmer, M., Overview of recent progress in Sm-Co based magnets. J. Iron Steel Res. Int. 2006, 13, 319-323. 
4. Fastenau, R. H. J.; van Loenen, E. J., Applications of rare earth permanent magnets. J. Magn. Magn. Mater. 1996, 157, 1-6.

5. Xie, F.; Zhang, T. A.; Dreisinger, D.; Doyle, F., A critical review on solvent extraction of rare earths from aqueous solutions. Miner. Eng. 2014, 56, 10-28.

6. Humphries, M., Rare earth elements: The global supply chain. Congressional Research Service 2013, 16 .

7. Charalampides, G.; Vatalis, K. I.; Apostoplos, B.; Ploutarch-Nikolas, B., Rare earth elements: industrial applications and economic dependency of Europe. Procedia Econ. Financ. 2015, 24, 126-135.

8. McColl, J. R.; Palilla, F. C., Use of rare earths in television and cathode ray phosphors. In Industrial Applications of Rare Earth Elements, Karl A. Gschneidner, J., Ed. American Chemical Society: 1981; Vol. 164, pp 177-193.

9. Yantasee, W.; Fryxell, G. E.; Addleman, R. S.; Wiacek, R. J.; Koonsiripaiboon, V.; Pattamakomsan, K.; Sukwarotwat, V.; Xu, J.; Raymond, K. N., Selective removal of lanthanides from natural waters, acidic streams and dialysate. J. Hazard. Mater. 2009, 168 (2-3), 1233-1238. 10. Tunsu, C.; Petranikova, M.; Ekberg, C.; Retegan, T., A hydrometallurgical process for the recovery of rare earth elements from fluorescent lamp waste fractions. Sep. Purif. Technol. 2016, 161, 172-186.

11. Wang, K.; Adidharma, H.; Radosz, M.; Wan, P.; Xu, X.; Russell, C. K.; Tian, H.; Fan, M.; Yu, J., Recovery of rare earth elements with ionic liquids. Green Chem. 2017, 19 (19), 4469-4493.

12. Alemrajabi, M.; Rasmuson, A. C.; Korkmaz, K.; Forsberg, K., Recovery of rare earth elements from nitrophosphoric acid solutions. Hydrometallurgy 2017, 169, 253-262.

13. Maes, S.; Zhuang, W.-Q.; Rabaey, K.; Alvarez-Cohen, L.; Hennebel, T., Concomitant leaching and electrochemical extraction of rare earth elements from monazite. Environ. Sci. Technol. 2017, 51 (3), 1654-1661.

14. Hong, G.; Wang, M.; Li, X.; Shen, L.; Wang, X.; Zhu, M.; Hsiao, B. S., Micro-nano structure nanofibrous p-sulfonatocalix[8]arene complex membranes for highly efficient and selective adsorption of lanthanum(iii) ions in aqueous solution. RSC adv. 2015, 5 (27), 21178-21188.

15. Riano, S.; Binnemans, K., Extraction and separation of neodymium and dysprosium from used $\mathrm{NdFeB}$ magnets: an application of ionic liquids in solvent extraction towards the recycling of magnets. Green Chem. 2015, 17 (5), 2931-2942.

16. Mohammadi, M.; Forsberg, K.; Kloo, L.; De La Cruz, J. M.; Rasmuson, Å., Separation of Nd (III), Dy (III) and Y (III) by solvent extraction using D2EHPA and EHEHPA. Hydrometallurgy 2015, 156, 215-224.

17. Jia, Q.; Tong, S.; Li, Z.; Zhou, W.; Li, H.; Meng, S., Solvent extraction of rare earth elements with mixtures of sec-octylphenoxy acetic acid and bis (2, 4, 4-trimethylpentyl) dithiophosphinic acid. Sep. Purif. Technol. 2009, 64 (3), 345-350.

18. Huang, X.; Dong, J.; Wang, L.; Feng, Z.; Xue, Q.; Meng, X., Selective recovery of rare earth elements from ion-adsorption rare earth element ores by stepwise extraction with HEH(EHP) and HDEHP. Green Chem. 2017, 19 (5), 1345-1352.

19. Beauvais, R. A.; Alexandratos, S. D., Polymer-supported reagents for the selective complexation of metal ions: an overview. React. Funct. Polym. 1998, 36 (2), 113-123.

20. Zhao, F.; Repo, E.; Song, Y.; Yin, D.; Hammouda, S. B.; Chen, L.; Kalliola, S.; Tang, J.; Tam, K. C.; Sillanpaa, M., Polyethylenimine-cross-linked cellulose nanocrystals for highly efficient recovery of rare earth elements from water and a mechanism study. Green Chem. 2017, 19 (20), 4816-4828. 
21. Ashour, R. M.; El-sayed, R.; Abdel-Magied, A. F.; Abdel-khalek, A. A.; Ali, M.; Forsberg, K.; Uheida, A.; Muhammed, M.; Dutta, J., Selective separation of rare earth ions from aqueous solution using functionalized magnetite nanoparticles: kinetic and thermodynamic studies. Chem. Eng. J. 2017, 327, 286-296.

22. Ashour, R. M.; Abdelhamid, H. N.; Abdel-Magied, A. F.; Abdel-Khalek, A. A.; Ali, M. M.; Uheida, A.; Muhammed, M.; Zou, X. D.; Dutta, J., Rare earth ions adsorption onto graphene oxide nanosheets. Solvent Extr. Ion Exch. 2017, 35 (2), 91-103.

23. Ogata, T.; Narita, H.; Tanaka, M., Adsorption behavior of rare earth elements on silica gel modified with diglycol amic acid. Hydrometallurgy 2015, 152, 178-182.

24. Nash, K. L.; Jensen, M. P., Analytical-scale separations of the lanthanides: a review of techniques and fundamentals. Sep. Sci. Technol. 2001, 36 (5-6), 1257-1282.

25. Santoyo, E.; Verma, S. P., Determination of lanthanides in synthetic standards by reversedphase high-performance liquid chromatography with the aid of a weighted least-squares regression model: Estimation of method sensitivities and detection limits. J. Chromatogr. A 2003, 997 (1), 171-182.

26. Roosen, J.; Binnemans, K., Adsorption and chromatographic separation of rare earths with EDTA-and DTPA-functionalized chitosan biopolymers. J. Mater. Chem. A 2014, 2 (5), 15301540.

27. Wei, Z.; Sandron, S.; Townsend, A.; Nesterenko, P.; Paull, B., Determination of trace labile copper in environmental waters by magnetic nanoparticle solid phase extraction and highperformance chelation ion chromatography. Talanta 2015, 135, 155-162.

28. McGillicuddy, N.; Nesterenko, E. P.; Nesterenko, P. N.; Jones, P.; Paull, B., Chelation ion chromatography of alkaline earth and transition metals a using monolithic silica column with bonded N-hydroxyethyliminodiacetic acid functional groups. J. Chromatogr. A 2013, 1276, 102111.

29. Roosen, J.; Van Roosendael, S.; Borra, C. R.; Van Gerven, T.; Mullens, S.; Binnemans, K., Recovery of scandium from leachates of Greek bauxite residue by adsorption on functionalized chitosan-silica hybrid materials. Green Chem. 2016, 18 (7), 2005-2013.

30. Nesterenko, P.; Jones, P., Isocratic separation of lanthanides and yttrium by high-performance chelation ion chromatography on iminodiacetic acid bonded to silica. J. Chromatogr. A 1998, 804 (1), 223-231.

31. Nesterenko, P., First isocratic separation of fourteen lanthanides and yttrium by highperformance chelation ion chromatography. Anal. Commun. 1997, 34 (1), 7-8.

32. Fryxell, G. E.; Chouyyok, W.; Rutledge, R. D., Design and synthesis of chelating diamide sorbents for the separation of lanthanides. Inorg. Chem. Commun. 2011, 14 (6), 971-974.

33. Ling, L.; Wang, N.-H. L., Ligand-assisted elution chromatography for separation of lanthanides. J. Chromatogr. A 2015, 1389, 28-38.

34. Inoue, Y.; Kumagai, H.; Shimomura, Y.; Yokoyama, T.; Suzuki, T. M., Ion chromatographic separation of rare-earth elements using a nitrilotriacetate-type chelating resin as the stationary phase. Anal. Chem. 1996, 68 (9), 1517-1520.

35. Suzuki, T., Liquid chromatographic selectivity and retention behavior of rare-earth elements on a chelating resin having a propylenediaminetetraacetate type functional group. Analyst 1999, 124 (11), 1595-1597.

36. Wu, H.; Watanabe, N.; Gohshi, Y.; Kotama, R., Mixture of HIBA and glycolic acid as eluent for effective separation of yttrium and dysprosium by HPLC. Fresenius J. Anal. Chem. 1999, 363 (4), 424-426. 
37. Robards, K.; Clarke, S.; Patsalides, E., Advances in the analytical chromatography of the lanthanides. A review. Analyst 1988, 113 (12), 1757-1779.

38. Max-Hansen, M., Modeling and optimization of rare earth element chromatography. Ph.D. thesis, Lund University, Faculty of Engineering, Dept. Chemical Engineering: 2014.

39. Ramzan, M.; Kifle, D.; Wibetoe, G., Comparative study of stationary phases impregnated with acidic organophosphorus extractants for HPLC separation of rare earth elements. Sep. Sci. Technol. 2016, 51 (3), 494-501.

40. Zhang, A.; Kuraoka, E.; Kumagai, M., Preparation of a novel macroporous silica-based 2,6bis(5,6-diisobutyl-1,2,4-triazine-3-yl)pyridine impregnated polymeric composite and its application in the adsorption for trivalent rare earths. J. Radioanal. Nucl. Chem. 2007, 274 (3), 455-464.

41. Zhang, A.; Kuraoka, E.; Kumagai, M., Group partitioning of minor actinides and rare earths from highly active liquid waste by extraction chromatography utilizing two macroporous silicabased impregnated polymeric composites. Sep. Purif. Technol. 2007, 54 (3), 363-372.

42. Zhang, A.; Hu, Q.; Wang, W.; Kuraoka, E., Application of a macroporous silica-based CMPOimpregnated polymeric composite in group partitioning of long-lived minor actinides from highly active liquid by extraction chromatography. Ind. Eng. Chem. Res. 2008, 47 (16), 6158-6165.

43. Zhang, A.; Wang, W.; Chai, Z.; Kuraoka, E., Modification of a novel macroporous silica-based crown ether impregnated polymeric composite with 1-dodecanol and its adsorption for some fission and non-fission products contained in high level liquid waste. Eur. Polym. J. 2008, 44 (11), 3899-3907.

44. Zhang, A.; Wei, Y.; Kumagai, M., Bleeding evaluation of the stationary phase from a few novel macroporous silica-substrate polymeric materials used for radionuclide partitioning from HLLW in MAREC process. J. Radioanal. Nucl. Chem. 2005, 265 (3), 409-417.

45. Vlasova, N. N.; Oborina, E. N.; Grigoryeva, O. Y.; Mikhail, G. V., Organosilicon ion-exchange and complexing adsorbents. Russian Chem.Rev. 2013, 82 (5), 449.

46. Melnyk, I. V.; Goncharyk, V. P.; Stolyarchuk, N. V.; Kozhara, L. I.; Lunochkina, A. S.; Alonso, B.; Zub, Y. L., Dy(III) sorption from water solutions by mesoporous silicas functionalized with phosphonic acid groups. J. Porous Mater. 2012, 19 (5), 579-585.

47. Seisenbaeva, G. A.; Melnyk, I. V.; Hedin, N.; Chen, Y.; Eriksson, P.; Trzop, E.; Zub, Y. L.; Kessler, V. G., Molecular insight into the mode-of-action of phosphonate monolayers as active functions of hybrid metal oxide adsorbents. Case study in sequestration of rare earth elements. RSC adv. 2015, 5 (31), 24575-24585.

48. Pogorilyi, R. P.; Melnyk, I. V.; Zub, Y. L.; Carlson, S.; Daniel, G.; Svedlindh, P.; Seisenbaeva, G. A.; Kessler, V. G., New product from old reaction: uniform magnetite nanoparticles from ironmediated synthesis of alkali iodides and their protection from leaching in acidic media. RSC $a d v$. 2014, 4 (43), 22606-22612.

49. Topel, S. D.; Legaria, E. P.; Tiseanu, C.; Rocha, J.; Nedelec, J.-M.; Kessler, V. G.; Seisenbaeva, G. A., Hybrid silica nanoparticles for sequestration and luminescence detection of trivalent rare-earth ions (Dy3+ and Nd3+) in solution. J. Nanopart. Res. 2014, 16 (12), 2783.

50. Fang, Q.; Duan, S.; Zhang, J.; Li, J.; Leung, K. C.-F., Dual shelled $\mathrm{Fe}_{3} \mathrm{O}_{4} /$ polydopamine hollow microspheres as an effective Eu(iii) adsorbent. J. Mater. Chem. A 2017, 5 (6), 2947-2958.

51. Polido Legaria, E.; Topel, S. D.; Kessler, V. G.; Seisenbaeva, G. A., Molecular insights into the selective action of a magnetically removable complexone-grafted adsorbent. Dalton Trans. 2015, 44 (3), 1273-1282. 
52. Ashour, R. M.; Abdel-Magied, A. F.; Abdel-khalek, A. A.; Helaly, O.; Ali, M., Preparation and characterization of magnetic iron oxide nanoparticles functionalized by l-cysteine: Adsorption and desorption behavior for rare earth metal ions. J. Environ.Chem. Eng. 2016, 4 (3), 3114-3121. 53. Dupont, D.; Luyten, J.; Bloemen, M.; Verbiest, T.; Binnemans, K., Acid-stable magnetic coreshell nanoparticles for the separation of rare earths. Ind. Eng. Chem. Res. 2014, 53 (39), 1522215229.

54. Duan, S.; Xu, X.; Liu, X.; Wang, Y.; Hayat, T.; Alsaedi, A.; Meng, Y.; Li, J., Highly enhanced adsorption performance of $\mathrm{U}(\mathrm{VI})$ by non-thermal plasma modified magnetic $\mathrm{Fe}_{3} \mathrm{O}_{4}$ nanoparticles. J. Colloid Interface Sci. 2018, 513, 92-103.

55. Duan, S.; Wang, Y.; Liu, X.; Shao, D.; Hayat, T.; Alsaedi, A.; Li, J., Removal of U(VI) from aqueous solution by amino functionalized flake graphite prepared by plasma treatment. $A C S$ Sustainable Chem. Eng. 2017, 5 (5), 4073-4085.

56. Zhang, H.; McDowell, R. G.; Martin, L. R.; Qiang, Y., Selective extraction of heavy and light lanthanides from aqueous solution by advanced magnetic nanosorbents. ACS Appl. Mater. Interfaces 2016, 8 (14), 9523-9531.

57. Almeida, S. d. N.; Toma, H. E., Neodymium(III) and lanthanum(III) separation by magnetic nanohydrometallurgy using DTPA functionalized magnetite nanoparticles. Hydrometallurgy 2016, 161, 22-28.

58. Roosen, J.; Spooren, J.; Binnemans, K., Adsorption performance of functionalized chitosansilica hybrid materials toward rare earths. J. Mater. Chem. A 2014, 2 (45), 19415-19426.

59. Grimes, T. S.; Nash, K. L., Acid dissociation constants and rare earth stability constants for DTPA. J. Solution Chem. 2014, 43 (2), 298-313.

60. Polido Legaria, E.; Samouhos, M.; Kessler, V. G.; Seisenbaeva, G. A., Toward molecular recognition of REEs: comparative analysis of hybrid nanoadsorbents with the different complexonate ligands EDTA, DTPA, and TTHA. Inorg. Chem. 2017, 56 (22), 13938-13948.

61. Dybczyński, R. S.; Kulisa, K.; Pyszynska, M.; Bojanowska-Czajka, A., New reversed phasehigh performance liquid chromatographic method for selective separation of yttrium from all rare earth elements employing nitrilotriacetate complexes in anion exchange mode. J. Chromatogr. A 2015, 1386, 74-80.

62. Parker, J., Peptide bond. In Encyclopedia of Genetics, Sydney Brenner, J. M., Ed. 2001; pp 1429-1430.

63. McGillicuddy, N.; Nesterenko, E. P.; Nesterenko, P. N.; Stack, E. M.; Omamogho, J. O.; Glennon, J. D.; Paull, B., A new N-hydroxyethyliminodiacetic acid modified core-shell silica phase for chelation ion chromatography of alkaline earth, transition and rare earth elements. $J$. Chromatogr. A 2013, 1321, 56-64. 